\title{
Noble Gas and Major Element Constraints on the Water Dynamics in an Alpine Floodplain
}

\author{
by Johannes Holocher1, Vijay Matta,3, Werner Aeschbach-Hertig1, \\ Urs Beyerle', Markus Hofer ${ }^{1}$, Frank Peeters ${ }^{1}$, and Rolf Kipfer ${ }^{1,2}$
}

\begin{abstract}
The hydrogeological system of an ecologically sensitive alpine floodplain in the Valle di Blenio, Switzerland, was investigated using hydrochemical and ${ }^{3}{ }_{-}-{ }^{3} \mathrm{He}$ dating methods. Water samples from six wells and from different surface locations were analyzed. The analysis of the concentrations of major ions in conjunction with age determination by the ${ }^{3} \mathrm{H}^{-}{ }^{3} \mathrm{He}-\mathrm{method}$ allowed the main hydrological properties of the system to be consistently characterized. Two geochemically distinct water zones can be distinguished: $\mathrm{Ca}_{-} \mathrm{SO}_{4}$-dominated water from the main river and $\mathrm{Ca}-\mathrm{HCO}_{3}$-dominated floodplain water. The floodplain water component characterizes the whole floodplain including the surficial hillslope drainage system. Within the ground water samples, two spatially and temporally different types of water can be determined. A younger (age $<1.5$ years), less mineralized water is found in the upper part of the aquifer during the summer season. The underlying aquifer zone contains older and more highly mineralized water. However, the general hydrochemical characterization of both types of ground water is similar. In winter, the water ages increase with decreasing ground water levels. Because precipitation is stored temporarily in the snow cover, the contribution of the younger near-surface ground water decreases, resulting in higher apparent water ages and higher mineralization in the upper zone of the aquifer. Water exchange between the main river and the ground water system is limited to ground water exfiltration from the shallow aquifer zone, whereas the hydrochemical separation of the deeper aquifer zone indicates the isolation of the deeper ground water from the main river.
\end{abstract}

\section{Introduction}

Riverine floodplains are a key element in the hydrology of catchment systems. Besides offering a widespread variety of habitats for flora and fauna of exceptional ecological importance (Ward et al. 1999), floodplains can influence the chemical river water quality (Hemond 1980; Tockner et al. 1999) and the stream discharge regime (Bradley 1996). Floodplains are becoming increasingly subject to anthropogenic disturbance due, for instance, to stream discharge regulations or the extraction of ground water for use as drinking water. To preserve their ecological and economical value, it is necessary to take measures to ensure that floodplains are used wisely. As a prerequisite, the flow and transport mechanisms in such systems must be known. Of special interest is the quantification of the hydrological connection between stream and floodplain aquifer and the different proportions of ground water and surface water existing within the floodplain (Alden and Munster 1997). This can be crucial-even on a conceptual level—because the hydrology of such

${ }^{1}$ Department of Water Resources and Drinking Water, Swiss Federal Institute of Environmental Science and Technology, P.O. Box 611, Ueberlandstrasse 133, CH-8600 Duebendorf, Switzerland; 0041-1-823 5531; fax 0041-1-823 5210; johannes.holocher@eawag.ch

${ }^{2}$ Isotope Geology, Department of Earth Sciences, Swiss Federal Institute of Science and Technology, NO C61, CH-8092 Zurich, Switzerland

${ }^{3}$ Now at Agriculture Western Australia, Locked Bag Four, Bentley Delivery Centre, WA 6983, Australia

Received August 2000, accepted May 2001. a system is often complex and reliable information on the water flow dynamics is seldom available.

The use of environmental tracers can help to provide this lacking knowledge, since these tracers are an important tool for the identification and quantification of different water components in hydrogeology. They allow ground water to be distinguished from surface water (Plummer et al. 2000), ground water contamination to be characterized (Dunkle Saphiro et al. 1999), and geochemical transformation processes to be identified (Mengis et al. 1999).

In this paper, tritium $\left({ }^{3} \mathrm{H}\right)$ and dissolved noble gases were used as environmental tracers in combination with hydrochemical data to gain more detailed insights into the mechanisms controlling the hydrology of a Swiss alpine floodplain in the Valle di Blenio. The combined isotopic-hydrochemical approach employed was particularly intended as an aid in determining possible interactions between stream water and ground water in this ecologically important floodplain.

\section{Study Area}

The Valle di Blenio is located in the southern Alps in the Canton of Ticino, Switzerland (Figure 1). Starting in Biasca (303 meters above sea level [masl]), the valley extends over $20 \mathrm{~km}$ in a north-south direction up to Olivone ( 890 masl). The River Brenno has two main source areas that join near Olivone: the Valle Santa Maria with the Passo del Lucomagno (1915 masl) and the Valle Camadra. There are three major floodplains along the Brenno. This study focuses on the middle floodplain on the western side of the Brenno between Grumo and Aquarossa. The vegetation of the floodplains in the Valle di Blenio consists mainly of meadows and 


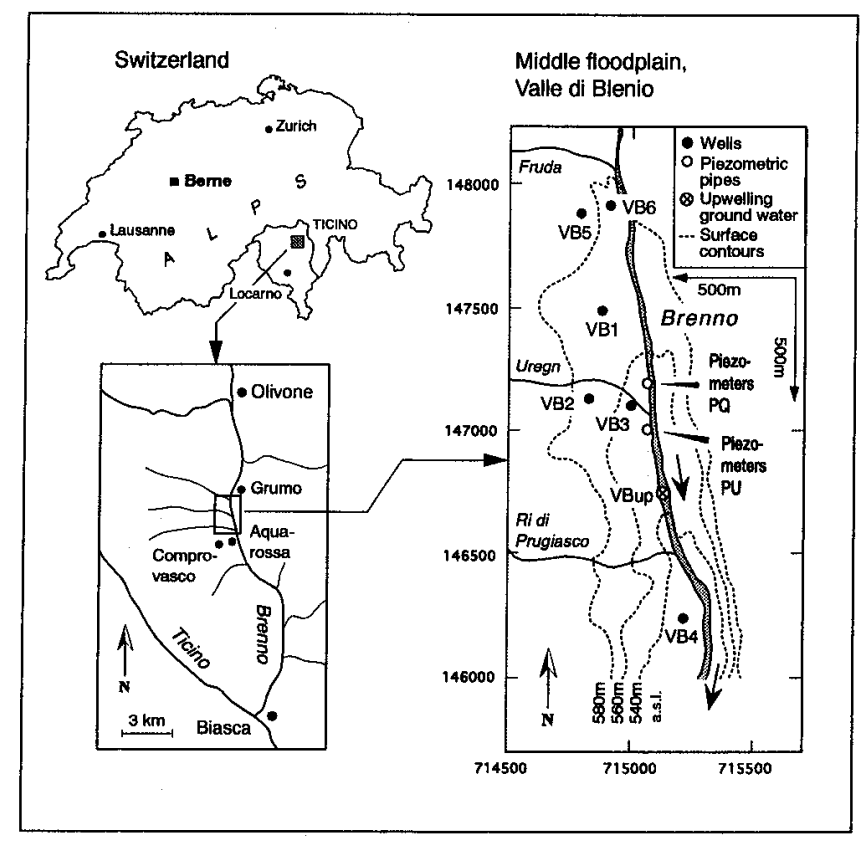

Figure 1. Study area.

partly wooded areas. These alpine floodplains with their typical flora and fauna are of such ecological importance that they are protected under Swiss federal legislation.

The River Brenno (average discharge: $4.75 \mathrm{~m}^{3} / \mathrm{sec}$ ) is strongly influenced by hydropower production within its catchment area. Three reservoirs with a combined capacity of up to $3.1 \cdot 10^{5} \mathrm{~m}^{3}$ and three hydropower plants (Biasca, Olivone, Luzzone) operate in the Brenno catchment area.

Geologically, the Blenio region is part of the lower penninic nappes in the Ticino sub-Dome (Pastorelli et al. 1999). It consists mainly of pre-Triassic crystalline series of gneiss and schists and carbonate-rich Mesozoic sediment layers. The crystalline and sediment layers were subjected to strong tectonic deformations associated with the updoming process. As a result, both types of layers were back-folded with a strong fracturing of the crystalline series (Preiswerk et al. 1934; Ammann 1973). The study area consists of gneiss and paragneiss of the Lucomagno-Leventina nappe and a dolomitic sediment cover layer, mainly in the northern part between Grumo and the Uregn tributary.

\section{Sample Collection and Analysis}

In this study, sampling was confined to the middle floodplain. Sampling was carried out in six wells (VB1 to VB6) and two groups of piezometers ( $\mathrm{PU}$ and $\mathrm{PQ}$ ), and in the Brenno and Uregn rivers (Figure 1). The diameters of the wells varied from $10 \mathrm{~cm}$ (VB2) to $14 \mathrm{~cm}$ (VB3) and their depths from $9.1 \mathrm{~m}$ (VB1) to $18.8 \mathrm{~m}$ (VB2). Each of the wells had a screened casing over its entire saturated length. The piezometers used were steel tubes of $4 \mathrm{~cm}$ diameter that extended from the surface down to depths of either 1.5 or $2 \mathrm{~m}$. The lowermost $70 \mathrm{~cm}$ of each piezometer were perforated. The ground water samples from the wells and piezometers were taken by submersible pumps from the depth indicated in Table 1 . To test whether the ground water accessible by the wells represents one homogeneous hydrochemical zone, profiles of temperature and electrical conductivity were measured in the wells prior to sampling.
If these profiles showed significant changes with depth, two samples from the upper and the lower part of the well screening were taken, employing a dual pumping technique (Rapp et al. 1998).

To record the annual evolution of the ground water system, five sampling campaigns were carried out between February 1998 and February 1999. In February 1999, an additional sample was taken from a spring on a small island within the active river bed of the Brenno (VBup). The upwelling water in this spring discharges at an elevation 3 to $5 \mathrm{~m}$ higher than the riverine water level. The temperature and electrical conductivity indicated that this spring releases ground water not affected by river water.

Water samples of $1 \mathrm{~L}$ were taken in PET bottles for chemical analysis and $45 \mathrm{~mL}$ were sealed off in copper tubes with pinch-off clamps (Kipfer 1991; Beyerle et al. 2000) to measure dissolved noble gases.

For all five sampling dates, analyses of major ions were conducted. Concentrations of noble gases $\left({ }^{3} \mathrm{He},{ }^{4} \mathrm{He}, \mathrm{Ne}, \mathrm{Ar}, \mathrm{Kr}, \mathrm{Xe}\right.$ ) were measured in the winter, spring, and summer samples of 1998, whereas the autumn samples of 1998 and the winter samples of 1999 were analyzed only for $\mathrm{He}$ and Ne. Tritium $\left({ }^{3} \mathrm{H}\right)$ was measured in the winter, spring, and autumn samples of 1998.

The mass spectrometric measurements of the noble gases were performed according to the procedures described by Beyerle et al. (2000). The tritium concentrations of the samples were measured by the ${ }^{3} \mathrm{He}$ ingrowth technique (Clarke et al. 1976; Beyerle et al. 2000).

\section{Ground Water Dating}

\section{${ }^{3} \mathrm{H}-{ }^{3} \mathrm{He}$ Age Calculation}

For the determination of water ages younger than 50 years, the radioactive hydrogen isotope tritium $\left({ }^{\circ} \mathrm{H}\right)$ with a half-life of 12.32 years (Lucas and Unterweger 2000) is widely used in hydrology. Large amounts of tritium were introduced into the atmosphere by atmospheric nuclear weapons tests mainly in the $1960 \mathrm{~s}$. With the incorporation of this bomb tritium into the hydrosphere, a time marker for water age determination was available. Additional information about the time elapsed since a water parcel was isolated from gas exchange with the atmosphere can be obtained if tritium and its decay product ${ }^{3} \mathrm{He}$ are considered together (Tolstikhin and Kamenskiy 1969). The ${ }^{3} \mathrm{H}-{ }^{3} \mathrm{He}$ age defines the time $\tau$ since the gas exchange of a water parcel has stopped, which is the time since the water entered the saturated zone, and is given by (Schlosser et al. 1989):

$$
\tau=\frac{1}{\lambda} \ln \left(1+\frac{\left[{ }^{3} \mathrm{He}_{\mathrm{tri}}\right]}{\left[{ }^{3} \mathrm{H}\right]}\right)
$$

$\lambda=0.0563 \mathrm{yr}^{-1}$ is the decay constant of ${ }^{3} \mathrm{H},\left[{ }^{3} \mathrm{H}\right]$ is the measured tritium concentration, and $\left[{ }^{3} \mathrm{He}_{\text {tri }}\right]$ is the tritiogenic ${ }^{3} \mathrm{He}$ that is produced in the sample. The conversion of concentration units needed to evaluate Equation 1 is given by $1 \mathrm{~cm}^{3} \mathrm{STP} / \mathrm{g}$ water $\cong$ $4.019 \times 10^{14} \mathrm{TU}$ for fresh water.

To calculate the ${ }^{3} \mathrm{H}-{ }^{3} \mathrm{He}$ age, it is essential to separate the tritiogenic ${ }^{3} \mathrm{He}\left({ }^{3} \mathrm{He}_{\text {tri }}\right)$ from the total measured ${ }^{3} \mathrm{He}\left({ }^{3} \mathrm{He}_{\mathrm{tot}}\right) \cdot{ }^{3} \mathrm{He}_{\text {tot }}$ can be resolved into components as follows (Schlosser et al. 1989; Aeschbach-Hertig et al. 1998):

$$
{ }^{3} \mathrm{He}_{\text {tot }}={ }^{3} \mathrm{He}_{\text {equ }}+{ }^{3} \mathrm{He}_{\text {exc }}+{ }^{3} \mathrm{He}_{\text {ter }}+{ }^{3} \mathrm{He}_{\text {tri }}
$$

${ }^{3} \mathrm{He}_{\text {equ }}$ is the concentration of ${ }^{3} \mathrm{He}$ in water in equilibrium with air, ${ }^{3} \mathrm{He}_{\text {exc }}$ is the excess air component generated by the dis- 
Table 1

Hydrochemical and Helium-Neon Data: Wells, Middle Floodplain, Valle di Blenio

\begin{tabular}{|c|c|c|c|c|c|c|c|c|c|c|c|c|c|c|c|}
\hline Sample & $\begin{array}{l}\text { SD } \\
(1)\end{array}$ & $\begin{array}{l}\text { Total } \\
\text { Depth } \\
\text { (m) (2) }\end{array}$ & $\begin{array}{l}\text { Depth of } \\
\text { Water } \\
\text { Level } \\
\text { (m) (2) }\end{array}$ & $\begin{array}{l}\text { f } \\
\text { Sample } \\
\text { Depth } \\
\text { (m) (2) }\end{array}$ & $\begin{array}{c}\mathbf{E C} \\
(\mu \mathrm{S} / \mathbf{c m})\end{array}$ & pH & $\begin{array}{c}\mathrm{T} \\
\left({ }^{\circ} \mathrm{C}\right)\end{array}$ & $\mathrm{Ca}^{2+}$ & $\begin{array}{r}\mathrm{Mg}^{2+} \\
(\mathrm{m}\end{array}$ & $\begin{array}{c}\mathbf{K}^{+} \\
[\mathbf{e q}] / \mathbf{L})\end{array}$ & $\mathrm{SO}_{4}{ }^{2-}$ & $\mathrm{HCO}_{3}^{-}$ & He & $\begin{array}{c}{ }^{4} \mathrm{He}_{\mathrm{rad}} \\
\left.\mathrm{n}^{3} \mathrm{STP} / \mathrm{g}\right) \text { (4) }\end{array}$ & $\mathrm{Ne}$ \\
\hline VB 1 & 1 & 9.1 & 3.58 & 8.5 & 492 & - & 9.2 & 3.48 & 1.60 & 0.091 & 2.57 & 2.57 & $1.54 \cdot 10^{-7}$ & $1.04 \cdot 10^{-7}$ & $2.10 \cdot 10^{-7}$ \\
\hline VB 3 & 1 & 10.3 & 2.75 & 9 & 420 & - & 7.0 & 2.92 & 1.38 & 0.092 & 1.77 & 2.69 & $1.40 \cdot 10^{-7}$ & $9.13 \cdot 10^{-8}$ & $2.09 \cdot 10^{-7}$ \\
\hline VB 4 & 1 & 10.3 & 4.69 & 9 & 380 & - & 8.3 & 2.56 & 1,42 & 0.098 & 0.76 & 3.30 & $1.06 \cdot 10^{-7}$ & $5.55 \cdot 10^{-8}$ & $2.16 \cdot 10^{-7}$ \\
\hline VB 5 & 1 & 14.4 & 9.47 & 13 & 546 & - & 10.3 & 3.98 & 1.74 & 0.103 & 3.13 & 2.67 & $1.20 \cdot 10^{-7}$ & $7.08 \cdot 10^{-8}$ & $2.07 \cdot 10^{-7}$ \\
\hline VB 6 & 1 & 10.9 & 3.50 & 9 & 666 & 一 & 8.8 & 4.60 & 2.46 & 0.114 & 4.31 & 2.87 & $1.73 \cdot 10^{-7}$ & $1.25 \cdot 10^{-7}$ & $2.05 \cdot 10^{-7}$ \\
\hline VB 1 & 2 & 9.1 & 1.65 & 8.5 & 415 & 8.0 & 9.2 & 3.38 & 1.50 & 0.085 & 0.86 & 3.76 & $8.43 \cdot 10^{-8}$ & $3.10 \cdot 10^{-8}$ & $2.31 \cdot 10^{-7}$ \\
\hline VB 2 & 2 & 18.8 & 11.46 & 17 & 313 & 7.7 & 8.7 & 2.62 & 1.10 & 0.075 & 0.46 & 2.99 & $6.08 \cdot 10^{-8}$ & $1.01 \cdot 10^{-8}$ & $2.21 \cdot 10^{-7}$ \\
\hline VB 3 & 2 & 10.3 & 2.62 & 4.5 & 347 & 8.0 & 8.6 & 2.80 & 1.27 & 0.083 & 1.22 & 2.57 & $1.44 \cdot 10^{-7}$ & $9.68 \cdot 10^{-8}$ & $2.03 \cdot 10^{-7}$ \\
\hline VB 3 & 2 & 10.3 & 2.62 & 9 & 661 & 7.4 & 10.3 & 3.60 & 1.58 & 0.089 & 1.76 & 2.97 & $2.31 \cdot 10^{-7}$ & $1.81 \cdot 10^{-7}$ & $2.17 \cdot 10^{-7}$ \\
\hline VB 4 & 2 & 10.3 & 4.24 & 9 & 388 & 8.0 & 9.3 & 3.14 & 1.57 & 0.101 & 0.72 & 3.66 & - & - & - \\
\hline VB 5 & 2 & 10.4 & 5.90 & 13 & 240 & 8.1 & 9.2 & 2.07 & 0.82 & 0.073 & 0.24 & 2.47 & $5.47 \cdot 10^{-8}$ & $1.03 \cdot 10^{-8}$ & $2.11 \cdot 10^{-7}$ \\
\hline VB 6 & 2 & 10.9 & 2.25 & 9 & 229 & 8.0 & 8.5 & 1.86 & 0.83 & 0.072 & 0.32 & 2.23 & - & - & - \\
\hline VB 1 & 3 & 9.1 & 2.61 & 4 & 251 & 7.9 & 10.7 & 2.04 & 0.88 & 0.074 & 0.24 & 2.42 & $5.59 \cdot 10^{-8}$ & $7.56 \cdot 10^{-9}$ & $2.08 \cdot 10^{-7}$ \\
\hline VB 1 & 3 & 9.1 & 2.61 & 8 & 251 & 8.0 & 10.7 & 2.14 & 0.94 & 0.073 & 0.24 & 2.46 & - & - & - \\
\hline VB 2 & 3 & 18.8 & 12.0 & 13 & 350 & 7.9 & 12 & 3.22 & 1.36 & 0.097 & 0.34 & 3.36 & $5.33 \cdot 10^{-8}$ & $1.31 \cdot 10^{-9}$ & $2.23 \cdot 10^{-7}$ \\
\hline VB 2 & 3 & 18.8 & 12.0 & 18 & 350 & 8.0 & 10.3 & 3.28 & 1.38 & 0.100 & 0.32 & 3.41 & $5.54 \cdot 10^{-8}$ & $2.33 \cdot 10^{-8}$ & $2.29 \cdot 10^{-7}$ \\
\hline VB 3 & 3 & 10.3 & 2.71 & 4 & 336 & 8.0 & 14.0 & 2.96 & 1.30 & 0.102 & 0.73 & 2.71 & - & - & - \\
\hline VB 3 & 3 & 10.3 & 2.71 & 5 & 336 & 7.9 & 13.9 & 3.02 & 1.34 & 0.103 & 0.82 & 2.75 & $1.05 \cdot 10^{-7}$ & $5.83 \cdot 10^{-8}$ & $1.99 \cdot 10^{-7}$ \\
\hline VB 3 & 3 & 10.3 & 2.71 & 8.5 & 580 & 7.9 & 10.5 & 5.52 & 2.86 & 0.128 & 2.96 & 3.49 & $6.71 \cdot 10^{-7}$ & $6.11 \cdot 10^{-7}$ & $2.47 \cdot 10^{-7}$ \\
\hline VB 5 & 3 & 10.4 & 7.98 & 11 & 204 & 8.0 & 10.3 & 1.52 & 0.60 & 0.058 & 0.19 & 1.96 & $5.40 \cdot 10^{-8}$ & $1.84 \cdot 10^{-9}$ & $2.20 \cdot 10^{-7}$ \\
\hline VB 6 & 3 & 10.9 & 1.75 & 4 & 270 & 7.9 & 12.3 & 2.16 & 0.86 & 0.070 & 0.33 & 2.56 & - & - & - \\
\hline VB 6 & 3 & 10.9 & 1.75 & 8 & 270 & 7.9 & 11.7 & 2.10 & 0.90 & 0.069 & 0.35 & 2.52 & $6.03 \cdot 10^{-8}$ & $1.02 \cdot 10^{-8}$ & $2.15 \cdot 10^{-7}$ \\
\hline VB 1 & 4 & 9.1 & 2.15 & 5.5 & 300 & 7.7 & 10.9 & 2.40 & 1.00 & 0.085 & 0.25 & 2.99 & $5.93 \cdot 10^{-8}$ & $1.07 \cdot 10-8$ & $2.09 \cdot 10^{-7}$ \\
\hline VB 2 & 4 & 18.8 & 12.03 & 15 & 160 & 7.9 & 11.6 & 2.60 & 1.04 & 0.091 & 0.34 & 2.88 & $5.20 \cdot 10^{-8}$ & $1.80 \cdot 10^{-9}$ & $2.15 \cdot 10^{-7}$ \\
\hline VB 3 & 4 & 10.3 & 2.66 & 6 & 160 & 7.9 & 10.6 & 2.38 & 1.00 & 0.091 & 0.56 & 2.48 & $8.58 \cdot 10^{-8}$ & $4.01 \cdot 10^{-8}$ & $1.97 \cdot 10^{-7}$ \\
\hline VB 4 & 4 & 10.3 & 4.39 & 7 & 410 & 7.7 & 11.7 & 3.17 & 1.62 & 0.121 & 0.78 & 3.75 & $7.76 \cdot 10^{-8}$ & $2.82 \cdot 10^{-8}$ & $2.11 \cdot 10^{-7}$ \\
\hline VB 5 & 4 & 10.4 & 6.47 & 9.5 & 220 & 7.9 & 10.6 & 1.92 & 0.76 & 0.070 & 0.34 & 2.30 & $4.87 \cdot 10^{-8}$ & $3.54 \cdot 10^{-9}$ & $1.95 \cdot 10^{-7}$ \\
\hline VB 6 & 4 & 10.9 & 2.57 & 6 & 237 & 7.8 & 10.3 & 1.76 & 0.68 & 0.073 & 0.22 & 2.19 & $5.96 \cdot 10^{-8}$ & $8.62 \cdot 10^{-9}$ & $2.19 \cdot 10^{-7}$ \\
\hline VB 1 & 5 & 9.1 & 3.72 & 6 & 300 & 8.0 & 9.0 & 2.20 & 1.12 & 0.074 & 0.71 & 2.48 & $9.86 \cdot 10^{-8}$ & $5.05 \cdot 10^{-9}$ & $2.09 \cdot 10^{-7}$ \\
\hline VB 2 & 5 & 18.8 & 12.63 & 15 & 269 & 8.0 & 9.1 & 2.00 & 1.00 & 0.066 & 0.34 & 2.58 & $4.91 \cdot 10^{-8}$ & $2.77 \cdot 10^{-9}$ & $2.01 \cdot 10^{-7}$ \\
\hline VB 3 & 5 & 10.3 & 2.81 & 9 & 263 & 8.0 & 8.3 & 2.00 & 1.20 & 0.063 & 0.75 & 2.38 & $8.64 \cdot 10^{-8}$ & $4.00 \cdot 10^{-9}$ & $2.09 \cdot 10^{-7}$ \\
\hline VB 5 & 5 & 10.4 & 9.40 & 12 & 420 & 8.0 & 9.6 & 3.02 & 1.54 & 0.092 & 2.12 & 2.29 & $4.27 \cdot 10^{-8}$ & $2.65 \cdot 10^{-9}$ & - \\
\hline VB 6 & 5 & 10.9 & 3.55 & 7 & 629 & 7.9 & 8.2 & 4.36 & 2.62 & 0.100 & 4.00 & 2.81 & $1.66 \cdot 10^{-7}$ & $1.21 \cdot 10^{-7}$ & $2.00 \cdot 10^{-7}$ \\
\hline VBup & 5 & - & - & 0 & 1209 & 7.9 & 10.8 & 11.80 & 5.68 & 0.190 & 11.88 & 5.56 & $2.60 \cdot 10^{-6}$ & $2.55 \cdot 10^{-6}$ & $1.99 \cdot 10^{-7}$ \\
\hline
\end{tabular}

(1) SD - Sample dates: 1: February 1998; 2: May 1998; 3: July 1998; 4: October 1998; 5: February 1999.

(2) Given in meters below ground surface.

(3) Average charge balance error: $5 \%$.

(4) Analytical precision: $\mathrm{He}: 0.4 \%$; Ne: $1 \%$

Data for samples with a complete noble gas data set $(\mathrm{He}, \mathrm{Ne}, \mathrm{Ar}, \mathrm{Kr}, \mathrm{Xe}$ ) can be obtained from the authors by request.

solution of small entrapped air bubbles in the upper part of the saturated zone (Heaton and Vogel 1981), ${ }^{3} \mathrm{He}_{\mathrm{ter}}$ is the terrigenic component derived from the earth's crust or mantle and ${ }^{3} \mathrm{He}_{\text {tri }}$ is the tritiogenic component. In the study area, the terrigenic ${ }^{3} \mathrm{He}$ is most likely of crustal origin, and therefore, henceforth described as radiogenic ${ }^{3} \mathrm{He}\left({ }^{3} \mathrm{He}_{\mathrm{rad}}\right)$. The equilibrium concentration is determined by temperature, salinity, and the atmospheric pressure (altitude) prevailing during ground water recharge. Measured Ne concentrations are commonly used to determine the excess air component, since the $\mathrm{Ne}$ in meteoric water is of atmospheric origin only, and hence the $\mathrm{Ne}$ balance consists of the equilibrium and the excess air components only. The tritiogenic ${ }^{3} \mathrm{He}$ can then be calculated as follows (Schlosser et al. 1989):

$$
\begin{aligned}
{ }^{3} \mathrm{He}_{\text {tri }}= & { }^{4} \mathrm{He}_{\text {tot }} \cdot\left(\mathrm{R}_{\mathrm{tot}}-\mathrm{R}_{\mathrm{rad}}\right)-{ }^{4} \mathrm{He}_{\text {equ }} \cdot\left(\mathrm{R}_{\text {equ }}-\mathrm{R}_{\mathrm{rad}}\right) \\
& -\mathrm{L}_{\text {exc }} \cdot\left(\mathrm{Ne}_{\text {tot }}-\mathrm{Ne}_{\text {equ }}\right) \cdot\left(\mathrm{R}_{\text {exc }}-\mathrm{R}_{\mathrm{rad}}\right)
\end{aligned}
$$

where $\mathrm{R}$ is the ${ }^{3} \mathrm{He} /{ }^{4} \mathrm{He}$ ratio of the respective component and $\mathrm{L}_{\text {exc }}$ is the $\mathrm{He} / \mathrm{Ne}$ ratio of the excess air. To calculate the ${ }^{3} \mathrm{H}-{ }^{3} \mathrm{He}$ water age, two quantities have to be established: the $\mathrm{He} / \mathrm{Ne}$ ratio of excess air $\left(\mathrm{L}_{\text {exc }}\right)$ and the ${ }^{3} \mathrm{He} /{ }^{4} \mathrm{He}$ ratio of the radiogenic component $\left(\mathrm{R}_{\mathrm{rad}}\right)$. Information about $\mathrm{L}_{\text {exc }}$ can be obtained from the analyses of the other atmospheric noble gases, $\mathrm{Ar}, \mathrm{Kr}$, and $\mathrm{Xe}$, and the comparison of the noble gas data with the predictions of different excess air models (Aeschbach-Hertig et al. 2000). Information about $\mathbf{R}_{\mathrm{rad}}$ may be derived from the dependence of the measured ${ }^{3} \mathrm{He} /{ }^{4} \mathrm{He}$ ratios on the He concentration, and in particular from those samples with the highest contributions of radiogenic He (Aeschbach-Hertig et al. 1998). In the following, we will discuss in detail how $L_{\text {exc }}$ and $R_{\text {rad }}$ were derived in this study, because their choice significantly influences the ${ }^{3} \mathrm{H}-{ }^{3} \mathrm{He}$ water ages and hence the overall interpretation of the ground water dynamics in the floodplain.

\section{Determination of the He/Ne Ratio of Excess Air}

Atmospheric gases in ground water are usually found to be oversaturated with respect to equilibrium conditions (Heaton and Vogel 1981; Andrews 1992; Wilson and McNeill 1997). This "excess air" phe- 
Table 2

Hydrochemical Data: Surface Water and Piezometers, Middle Floodplain, Valle di Blenio

\begin{tabular}{|c|c|c|c|c|c|c|c|c|c|c|c|c|}
\hline Sample & $\begin{array}{l}\text { SD } \\
\text { (1) }\end{array}$ & $\begin{array}{l}\text { Total } \\
\text { Depth } \\
\text { (m) (2) }\end{array}$ & $\begin{array}{l}\text { Depth of } \\
\text { Water } \\
\text { Level } \\
(\mathbf{m})(2)\end{array}$ & $\begin{array}{l}\text { Sampled } \\
\text { Depth } \\
(\mathbf{m})(2)\end{array}$ & $\begin{array}{c}\mathbf{E C} \\
(\mu \mathrm{S} / \mathbf{c m})\end{array}$ & pH & $\begin{array}{c}\mathbf{T} \\
\left({ }^{\circ} \mathbf{C}\right)\end{array}$ & $\mathrm{Ca}^{2+}$ & $\mathbf{M g}^{2+}$ & $\underset{(\mathbf{m m o l}[\mathrm{eq}] / \mathbf{L})(3)}{\mathbf{K}^{+}}$ & $\mathrm{SO}_{4}^{2-}$ & $\mathrm{HCO}_{3}^{-}$ \\
\hline Uregn & 1 & - & - & 0 & 240 & - & 2.3 & 1.60 & 0.90 & 0.054 & 0.54 & 1.98 \\
\hline Uregn & 1 & - & - & 0 & 240 & - & 2.3 & 1.60 & 0.90 & 0.054 & 0.54 & 1.98 \\
\hline Uregn & 2 & - & - & 0 & 198 & 8.3 & 8.9 & 1.67 & 0.68 & 0.047 & 0.31 & 1.95 \\
\hline Uregn & 3 & - & - & 0 & 207 & 8.1 & - & 1.80 & 0.74 & 0.043 & 0.40 & 2.10 \\
\hline Uregn & 4 & - & - & 0 & 221 & 8.1 & 21.6 & 2.32 & 1.06 & 0.065 & 0.49 & 2.14 \\
\hline Uregn & 5 & - & - & 0 & 126 & 8.1 & 6.3 & 1.94 & 0.82 & 0.068 & 0.37 & 2.11 \\
\hline Uregn & 6 & - & - & 0 & 203 & 8.0 & 1.3 & 1.58 & 1.06 & 0.049 & 0.46 & 2.04 \\
\hline Brenno & 2 & - & - & 0 & 527 & 8.0 & 10.6 & 4.96 & 1.43 & 0.102 & 3.69 & 2.21 \\
\hline Brenno & 3 & - & - & 0 & 515 & 8.0 & - & 4.92 & 1.36 & 0.094 & 3.56 & 2.09 \\
\hline Brenno & 4 & - & - & 0 & 538 & 7.9 & 16.5 & 6.54 & 1.82 & 0.132 & 4.12 & 2.27 \\
\hline Brenno & 5 & - & - & 0 & 505 & 7.9 & 8.2 & 6.05 & 1.40 & 0.111 & 3.99 & 2.18 \\
\hline Brenno & 6 & - & - & 0 & 649 & 8.1 & 3.6 & 6.56 & 2.02 & 0.114 & 5.76 & 2.38 \\
\hline PU 119 & 5 & 1.5 & 0.88 & 1 & 313 & 7.4 & - & 2.58 & 1.14 & 0.099 & 0.60 & 3.23 \\
\hline PU 219 & 5 & 1.5 & 0.8 & 1 & 331 & 7.5 & - & 2.68 & 1.28 & 0.100 & 0.67 & 3.41 \\
\hline PU 214 & 5 & 1.5 & 0.85 & 1 & 320 & 7.5 & - & 2.56 & 1.24 & 0.098 & 0.71 & 3.23 \\
\hline PU 319 & 5 & 2 & 1.60 & 1.8 & 277 & 7.7 & - & 2.28 & 1.00 & 0.092 & 0.62 & 2.76 \\
\hline PU 419 & 5 & 2 & 1.65 & 1.8 & 313 & 7.7 & - & 2.52 & 1.18 & 0.112 & 0.90 & 2.91 \\
\hline PU 219 & 6 & 1.5 & 0.89 & 1 & 296 & 8.0 & - & 2.44 & 1.30 & 0.080 & 0.79 & 2.92 \\
\hline PQ 119 & 5 & 1.5 & 0.85 & 1 & 499 & 7.7 & - & 4.34 & 1.66 & 0.157 & 3.58 & 2.60 \\
\hline PQ 114 & 5 & 1.5 & 0.85 & 1 & 496 & 7.7 & - & 4.38 & 1.62 & 0.155 & 3.57 & 2.57 \\
\hline PQ 219 & 5 & 1.5 & 0.8 & 1 & 497 & 7.7 & - & 4.34 & 1.60 & 0.153 & 3.58 & 2.59 \\
\hline PQ 214 & 5 & 1.5 & 0.8 & 1 & 489 & 7.7 & - & 4.24 & 1.66 & 0.163 & 3.48 & 2.49 \\
\hline PQ 119 & 6 & 1.5 & 0.75 & 1 & 595 & 8.0 & - & 5.96 & 2.02 & 0.122 & 5.26 & 2.40 \\
\hline PQ 114 & 6 & 1.5 & 0.8 & 1 & 630 & 7.9 & - & 6.10 & 2.06 & 0.119 & 5.35 & 2.54 \\
\hline PQ 214 & 6 & 1.5 & 0.8 & 1 & 631 & 7.9 & - & 6.12 & 2.06 & 0.123 & 5.30 & 2.42 \\
\hline PQ 219 & 6 & 1.5 & 0.87 & 1 & 627 & 7.9 & - & 5.90 & 2.08 & 0.122 & 5.22 & 2.41 \\
\hline $\begin{array}{l}\text { (1) SD-s } \\
\text { (2) Given } \\
\text { (3) Averag }\end{array}$ & ha & 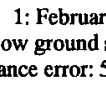 & $\begin{array}{l}88 ; 2 \\
\text { ce. }\end{array}$ & & & & & & & & & \\
\hline
\end{tabular}

nomenon has to be taken carefully into account when calculating recharge temperatures from dissolved noble gas concentrations in ground water (Stute and Schlosser 1993; Aeschbach-Hertig et al. 1999). For this calculation the contributions of excess air and solubility equilibrium to the total measured noble gas concentrations have to be resolved. This is done by conceptualizing the excess air component either as (1) pure atmospheric air, (2) air fractionated by partial degassing of an initial excess across the ground water table (Stute et al. 1995), or (3) air fractionated by equilibration of a finite entrapped air volume with a finite water volume in the quasi-saturated zone (Aeschbach-Hertig et al. 2000). Unfractionated excess air has the atmospheric $\mathrm{He} / \mathrm{Ne}$ ratio 0.288 . If the excess air is fractionated by diffusive degassing, $\mathrm{L}_{\mathrm{exc}}$ can adopt any value between zero and 0.288 . If fractionation is the result of closed-system equilibration with entrapped air, $\mathrm{L}_{\text {exc }}$ is constrained to range between the $\mathrm{He} / \mathrm{Ne}$ ratio of air and that of air-saturated water ( 0.23 to 0.25 , depending on temperature).

We applied the inverse technique of Aeschbach-Hertig et al. (1999) for the interpretation of noble gas data to those samples from the Valle di Blenio for which all noble gases had been analyzed, in order to judge which of the proposed excess air models correctly describes the data. The results permitted us to determine the appropriate values of $\mathrm{L}_{\text {exc }}$ (Table 3). During winter the excess air composition of all samples can be explained by unfractionated excess air $\left(\mathrm{L}_{\text {exc }}=0.288\right)$. In spring and summer, the excess air component was generated by finite air/water volume equilibration (Aeschbach-
Hertig et al. 2000), which results in a significantly lower $\mathrm{L}_{\text {exc }}$. The mean value for $\mathrm{L}_{\mathrm{exc}}$ of 0.244 that characterizes the spring and summer situation was also assigned to the autumn samples for which no complete noble gas data are available. This assumption was motivated by the hydrochemical data, which indicate that the autumn samples are hydrochemically similar to the summer samples. As the ground water upwelling at VBup was sampled in February 1999, its excess air component is described by the atmospheric $\mathrm{He} / \mathrm{Ne}$ ratio $(0.288)$ that reflects the winter situation.

The use of the best estimate of $\mathrm{L}_{\mathrm{exc}}$ yields more reasonable results for the calculated tritiogenic and radiogenic He components than the usual choice of the atmospheric $\mathrm{L}_{\text {exc }}$, and hence increases the accuracy of the calculated ${ }^{3} \mathrm{H}-{ }^{3} \mathrm{He}$ ages. For example, atmospheric $\mathrm{L}_{\text {exc }}$ yields negative values for ${ }^{3} \mathrm{He}_{\text {tri }}$ and therefore negative ${ }^{3} \mathrm{H}-{ }^{3} \mathrm{He}$ ages for $\mathrm{VB1}$ and $\mathrm{VB} 2$ in summer, whereas the use of the correct fractionated $\mathrm{L}_{\mathrm{exc}}$ for these samples results in small but positive ages that are realistic for the summer situation.

For the samples for which all five noble gases were analyzed, noble gas temperatures were calculated by applying the respective excess air model (Table 3 ). The calculated average recharge temperature of $9.4^{\circ} \mathrm{C} \pm 1.8^{\circ} \mathrm{C}$ for the middle floodplain, assuming a mean elevation of 580 masl, agrees reasonably well with the mean annual air temperature of $10.4^{\circ} \mathrm{C}$ determined for the same elevation on the basis of the 10-year data set, 1989 to 1999 , measured at the Comprovasco meteorological station (Figure 1). 
Table 3

Apparent Water Ages and Calculated Noble Gas Temperatures, Middle Floodplain, Valle di Blenio

\begin{tabular}{|c|c|c|c|c|c|c|c|c|c|}
\hline Sample & $\begin{array}{l}\text { SD } \\
\text { (1) }\end{array}$ & $\begin{array}{c}\text { Sample } \\
\text { Depth } \\
\text { (m) (2) }\end{array}$ & $\begin{array}{c}{ }^{3} \mathbf{H} \\
(\mathbf{T U})\end{array}$ & $\begin{array}{c}{ }^{3} \mathbf{H e}_{\text {tri }} \\
\text { (TU) }\end{array}$ & $\begin{array}{c}\text { Age } \\
\text { (year) }\end{array}$ & $\begin{array}{c}\text { NGT } \\
\left({ }^{\circ} \mathrm{C}\right) \\
(3)\end{array}$ & $\begin{array}{c}\Delta \mathrm{Ne} \\
(\%) \\
(4)\end{array}$ & $\begin{array}{c}\text { Model } \\
\text { (5) }\end{array}$ & $\begin{array}{l}L_{\text {exc }} \\
\text { (6) }\end{array}$ \\
\hline VB 1 & 1 & 8.5 & $12.66 \pm 0.55$ & $6.41 \pm 0.92$ & $7.3 \pm 0.9$ & $8.4 \pm 0.3$ & 10.0 & EA & 0.288 \\
\hline VB 3 & 1 & 9 & $13.68 \pm 0.61$ & $3.53 \pm 0.82$ & $4.1 \pm 0.9$ & $5.8 \pm 0.3$ & 6.5 & EA & 0.288 \\
\hline VB 4 & 1 & 9 & $14.09 \pm 0.61$ & $6.04 \pm 0.59$ & $6.4 \pm 0.6$ & $7.5 \pm 0.3$ & 12.2 & EA & 0.288 \\
\hline VB 5 & 1 & 13 & $15.19 \pm 0.57$ & $7.70 \pm 0.68$ & $7.3 \pm 0.6$ & $8.7 \pm 0.3$ & 8.5 & $\mathrm{EA}$ & 0.288 \\
\hline VB 6 & 1 & 9 & $14.75 \pm 0.60$ & $5.11 \pm 1.07$ & $5.3 \pm 1.0$ & $8.3 \pm 0.3$ & 7.0 & EA & 0.288 \\
\hline VB 1 & 2 & 8.5 & $10.61 \pm 0.15$ & $2.73 \pm 0.47$ & $4.1 \pm 0.6$ & $9.5 \pm 2.1$ & 22.3 & $\mathrm{CE}$ & 0.236 \\
\hline VB 2 & 2 & 17 & $11.02 \pm 0.15$ & $1.31 \pm 0.25$ & $2.0 \pm 0.4$ & $11.0 \pm 0.8$ & 19.2 & $\mathrm{CE}$ & 0.234 \\
\hline VB 3 & 2 & 4.5 & $11.99 \pm 0.16$ & $4.48 \pm 0.86$ & $5.7 \pm 0.9$ & $9.3 \pm 0.5$ & 7.6 & $\mathrm{CE}$ & 0.232 \\
\hline VB 3 & 2 & 9 & $12.04 \pm 0.15$ & $6.98 \pm 1.48$ & $8.2 \pm 1.4$ & - & - & - & 0.244 \\
\hline VB 5 & 2 & 13 & $9.60 \pm 0.15$ & $0.69 \pm 0.24$ & $1.2 \pm 0.4$ & - & - & - & 0.244 \\
\hline VB 1 & 3 & 4 & $10.36 \pm 2.44(7)$ & $0.32 \pm 0.42$ & $0.5 \pm 0.7$ & $9.6 \pm 1.0$ & 10.3 & $\mathrm{CE}$ & 0.241 \\
\hline VB 2 & 3 & 13 & $10.36 \pm 2.44(7)$ & $0.07 \pm 0.39$ & $0.1 \pm 0.7$ & $9.7 \pm 0.8$ & 18.5 & $\mathrm{CE}$ & 0.234 \\
\hline VB 2 & 3 & 18 & $10.36 \pm 2.44(7)$ & $0.56 \pm 0.40$ & $0.9 \pm 0.7$ & $11.1 \pm 2.0$ & 23.1 & $\mathrm{CE}$ & 0.238 \\
\hline VB 3 & 3 & 5 & $10.36 \pm 2.44(7)$ & $1.78 \pm 0.59$ & $2.8 \pm 1.1$ & $13.8 \pm 1.0$ & 9.4 & $\mathrm{CE}$ & 0.247 \\
\hline VB 3 & 3 & 8.5 & $10.36 \pm 2.44(7)$ & $18.21 \pm 4.95$ & $18.1 \pm 4.1$ & $9.4 \pm 0.6$ & 30.4 & $\mathrm{CE}$ & 0.255 \\
\hline VB 5 & 3 & 11 & $10.36 \pm 2.44(7)$ & $0.80 \pm 0.44$ & $1.3 \pm 0.8$ & $9.1 \pm 0.5$ & 15.9 & $\mathrm{CE}$ & 0.277 \\
\hline VB 6 & 3 & 8 & $8.84 \pm 0.14$ & $0.38 \pm 0.41$ & $0.8 \pm 0.8$ & $9.2 \pm 1.2$ & 13.2 & $\mathrm{CE}$ & 0.239 \\
\hline VB 1 & 4 & 5.5 & $9.76 \pm 0.27$ & $1.36 \pm 0.45$ & $2.3 \pm 0.7$ & - & - & - & 0.244 \\
\hline VB 2 & 4 & 15 & $10.04 \pm 0.19$ & $0.38 \pm 0.46$ & $0.7 \pm 0.8$ & - & - & - & 0.244 \\
\hline VB 3 & 4 & 6 & $11.43 \pm 0.20$ & $1.82 \pm 0.54$ & $2.6 \pm 0.7$ & - & - & - & 0.244 \\
\hline VB 4 & 4 & 7 & $12.16 \pm 0.23$ & $4.57 \pm 0.51$ & $5.7 \pm 0.6$ & - & - & - & 0.244 \\
\hline \multirow{2}{*}{$\begin{array}{l}\text { VB } 5 \\
\text { VB } 6\end{array}$} & 4 & 9.5 & $9.88 \pm 0.19$ & $1.93 \pm 0.42$ & $3.2 \pm 0.6$ & - & - & - & 0.244 \\
\hline & 4 & 6 & $3.60 \pm 0.16$ & $3.00 \pm 0.53$ & $10.6 \pm 1.5$ & - & - & - & 0.244 \\
\hline VBup & 5 & 0 & $13.75 \pm 0.16$ & $39.84 \pm 20.55$ & $24.3 \pm 6.9$ & - & - & - & 0.288 \\
\hline PU 214 & 4 & 1 & $10.10 \pm 0.18$ & $6.04 \pm 1.03$ & $8.4 \pm 1.1$ & - & - & - & 0.244 \\
\hline PQ 214 & 4 & 1 & $11.72 \pm 0.19$ & $0.82 \pm 0.41$ & $1.2 \pm 0.6$ & - & - & - & 0.244 \\
\hline \multirow{5}{*}{$\begin{array}{ll}\text { (1) } & \mathrm{SD}: \\
\text { (2) } & \\
\text { (3) } & \mathrm{NGT}: \\
\text { (4) } & \Delta \mathrm{Ne}: \\
\text { (5) } & \text { Model: } \\
\text { (6) } & \mathrm{L}_{\text {exc: }}\end{array}$} & $\begin{array}{l}\text { Samp } \\
\text { Giver }\end{array}$ & $\begin{array}{l}\text { ates: } 1: \mathrm{Fe} \\
\text { meters bel }\end{array}$ & $\begin{array}{l}\text { 1998; 2: May } 1998 \\
\text { und. }\end{array}$ & $98 ; 4:$ October & ary 1999. & & & & \\
\hline & Noble & as temperatu & lerived from the dissolv & ble gases. & & & & & \\
\hline & Ne sup & rsaturation d & 0 excess air, $\Delta \mathrm{Ne}=(\mathbb{N}$ & $\mathrm{Nc}_{\mathrm{equ}} / \mathrm{N} \mathrm{c}_{\mathrm{equ}}$ & & & & & \\
\hline & EA: un & ractionated $\mathrm{e}$ & ss air; CE: closed-syste & ilibration (Aeschbac & et al. 2000). & & & & \\
\hline & $\begin{array}{l}\mathrm{He} / \mathrm{Ne} \\
\text { This ra }\end{array}$ & atio of the ex & $s$ air component as pre & by the chosen exces & d. & . & 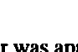 & & \\
\hline (7) & $\begin{array}{l}\text { For the } \\
\text { was ass }\end{array}$ & $\begin{array}{l}\text { samples no } \\
\text { ned. }\end{array}$ & m concentrations w & sured. A mean triti & ntration for the & ason (samplir & say, I & ober) of & $\pm 2.44 \mathrm{TU}$ \\
\hline
\end{tabular}

\begin{tabular}{|c|c|c|c|c|}
\hline \multicolumn{5}{|c|}{$\begin{array}{c}\text { Table } 4 \\
{ }^{3} \mathrm{H}^{-3} \mathrm{He} \text { Ages and } \mathrm{Mg}^{2+} \text { Accumulation Ages for VBup } \\
\text { and the Bottom Water Layer of VB3 }\end{array}$} \\
\hline & $\begin{array}{l}\text { VB3 (9 m, } \\
{ }^{3} \mathrm{H}-{ }^{3} \text { He Age }\end{array}$ & $\begin{array}{l}\text {, July 1998) } \\
\mathbf{M g}^{2+} \\
\text { Accumulation } \\
\text { Age }\end{array}$ & VI & $\begin{array}{l}\text { Bup } \\
\mathbf{M g}^{2+} \\
\text { Accumulation } \\
\text { Age }\end{array}$ \\
\hline $\begin{array}{l}R_{\mathrm{rad}}=2.0 \cdot 10^{-8} \\
\mathrm{R}_{\mathrm{rad}}=7.9 \cdot 10^{-8} \\
\mathrm{R}_{\mathrm{rad}}=6.0 \cdot 10^{-8}\end{array}$ & $\begin{array}{l}24.2 \text { years } \\
15.5 \text { years } \\
18.5 \text { years }\end{array}$ & $\begin{array}{l}15.1 \text { years } \\
10.8 \text { years } \\
12.3 \text { years }\end{array}$ & $\begin{array}{l}34.5 \text { years } \\
16.2 \text { years } \\
24.3 \text { years }\end{array}$ & $\begin{array}{l}33.8 \text { years } \\
24.3 \text { years } \\
27.6 \text { years }\end{array}$ \\
\hline
\end{tabular}

\section{Determination of the Radiogenic ${ }^{3} \mathrm{He} /{ }^{4} \mathrm{He}$ \\ Ratio in Ground Water}

To determine the isotopic composition of the radiogenic He component, following Stute et al. (1992) and Aeschbach-Hertig et al. (1998) we plotted ${ }^{3} \mathrm{He} /{ }^{4} \mathrm{He}$, corrected for excess air, against the reciprocal of the ${ }^{4} \mathrm{He}$ concentration, corrected for excess air and normalized to the solubility equilibrium concentration ${ }^{4} \mathrm{He}_{\text {equ }}$ (Figure 2). All samples lie close to the mixing line between air- saturated water (ASW) and the sample with the lowest ${ }^{3} \mathrm{He} /{ }^{4} \mathrm{He}$ ratio, VBup. The samples are shifted above this mixing line and so contain an additional ${ }^{3} \mathrm{He}$ component that is tritiogenic. Even sample VBup is tritium-active (13.8 TU) and most probably also contains tritiogenic ${ }^{3} \mathrm{He}$. Therefore the mixing line does not define $\mathrm{R}_{\mathrm{rad}}$ itself, but only an upper limit to $\mathrm{R}_{\mathrm{rad}}\left(9.85 \cdot 10^{-8}\right.$ from the intercept of the line).

In order better to constrain $\mathrm{R}_{\mathrm{rad}}$, one can assume that the amount of ${ }^{4} \mathrm{He}_{\text {rad }}$ increases linearly with ground water residence time owing to continous ${ }^{4} \mathrm{He}_{\mathrm{rad}}$ accumulation (Heaton 1984; Beyerle et al. 1999). Generally, the amounts of ${ }^{4} \mathrm{He}_{\mathrm{rad}}$ in the samples are relatively large (Table 1). This probably reflects the high ${ }^{4} \mathrm{He}_{\mathrm{rad}}$ production rate in pre-Mesozoic gneissic rock in the Blenio area. Furthermore this may indicate the existence of a ${ }^{4} \mathrm{He}_{\mathrm{rad}}$ flux into the aquifer that need not necessarily be associated with a ground water flow. Considering the small spatial dimension of the study area, the ${ }^{4} \mathrm{He}_{\mathrm{rad}}$ sources are not expected to vary strongly, hence all samples can be used to determine the ${ }^{4} \mathrm{He}_{\text {rad }}$ accumulation rate. For the measured samples, Figure 3 shows the relationship of ${ }^{3} \mathrm{H}-{ }^{3} \mathrm{He}$ ages to ${ }^{4} \mathrm{He}_{\mathrm{rad}}$ concentrations for different values of $\mathrm{R}_{\mathrm{rad}}$. The typical radi- 


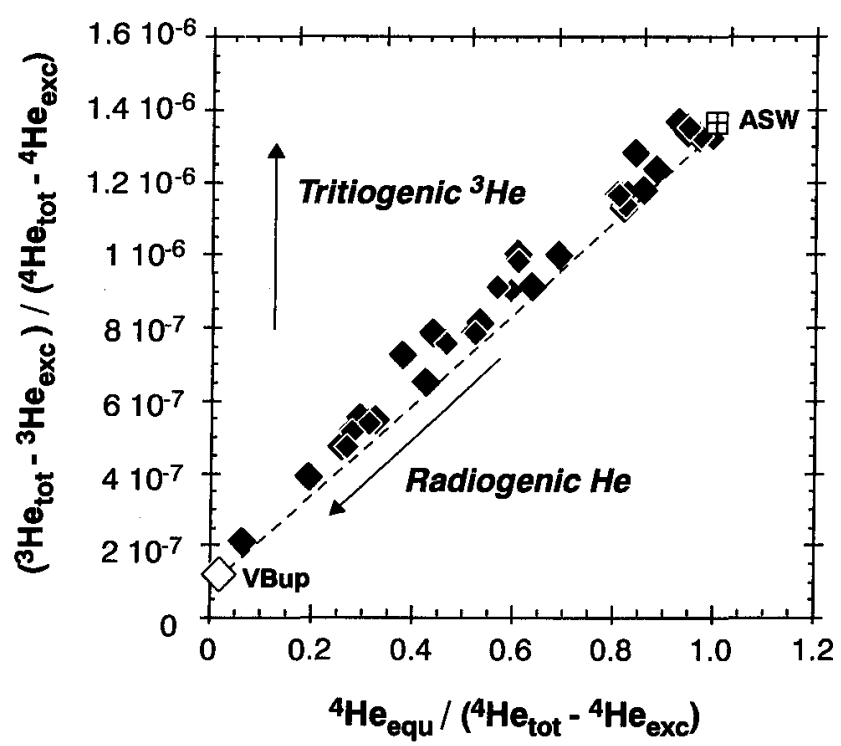

Figure $2 .{ }^{3} \mathrm{He} /{ }^{4} \mathrm{He}$ ratios of ground water samples, corrected for excess air, versus the reciprocal of the ${ }^{4} \mathrm{He}$ concentrations, corrected for excess air and normalized to the solubility equilibrium ${ }^{4} \mathrm{He}_{\text {equ }}$. Because all samples contain tritiogenic ${ }^{3} \mathrm{He}$, they have significantly higher ${ }^{3} \mathrm{He} /{ }^{4} \mathrm{He}$ ratios than would be expected from binary mixing between air-saturated water $\mathrm{ASW}$ and the radiogenic ${ }^{4} \mathrm{He}$-dominated upwelling ground water at VBup.

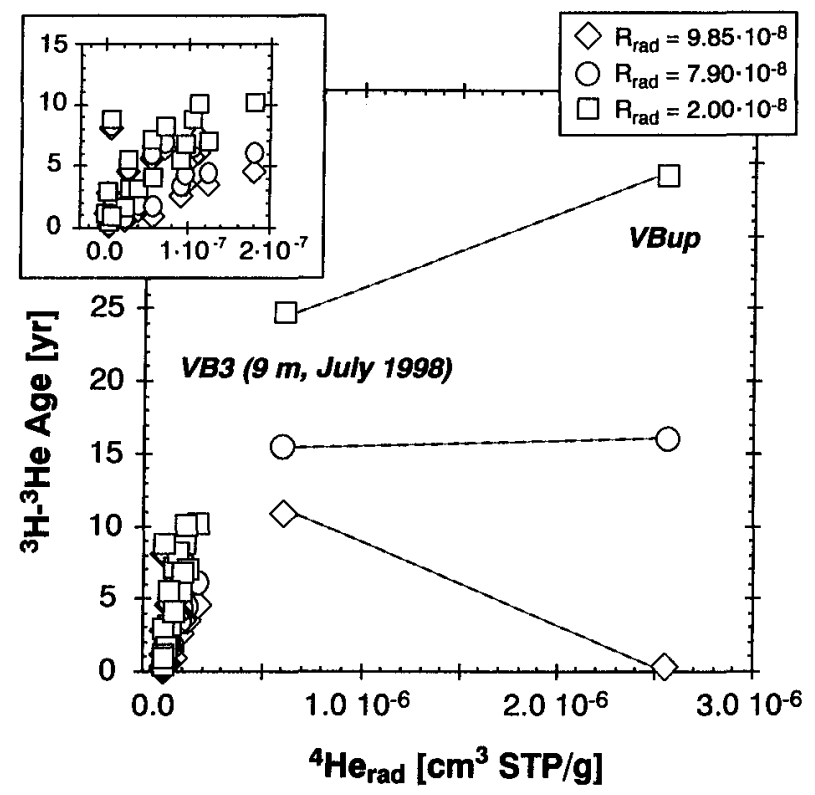

Figure 3. ${ }^{3} \mathrm{H}-{ }^{3} \mathrm{He}$ ages calculated for different values of the radiogenic ${ }^{3} \mathrm{He} /{ }^{4} \mathrm{He}$ ratio $\left(R_{\text {rad }}\right.$ ) versus the radiogenic ${ }^{4} \mathrm{He}$ component. As the ${ }^{4} \mathrm{He}_{\text {rad }}$ concentration is expected to increase with increasing water age, the upper limit for $\mathbf{R}_{\text {rad }}$ can be set to $7.9 \cdot 10^{-8}$. Larger values for $\mathbf{R}_{\text {rad }}$ result in ages for VBup that are unrealistically small compared to the high ${ }^{4} \mathbf{H e}_{\text {rad }}$ enrichment in this sample.

ogenic value of $R_{\text {rad }}$ from crustal $U / T h$-decay is $2 \cdot 10^{-8}$ (Mamyrin and Tolstikhin 1984), whereas $R_{\text {rad }}=9.85 \cdot 10^{-8}$ is defined by Figure 2. Those samples that contain only small amounts of ${ }^{4} \mathrm{He}_{\mathrm{rad}}$ show little variation in the ${ }^{3} \mathrm{H}-{ }^{3} \mathrm{He}$ ages calculated, and as a result the choice of $R_{\text {rad }}$ has only a slight influence on the age calculation. The opposite is true for the samples that are highly enriched in radiogenic

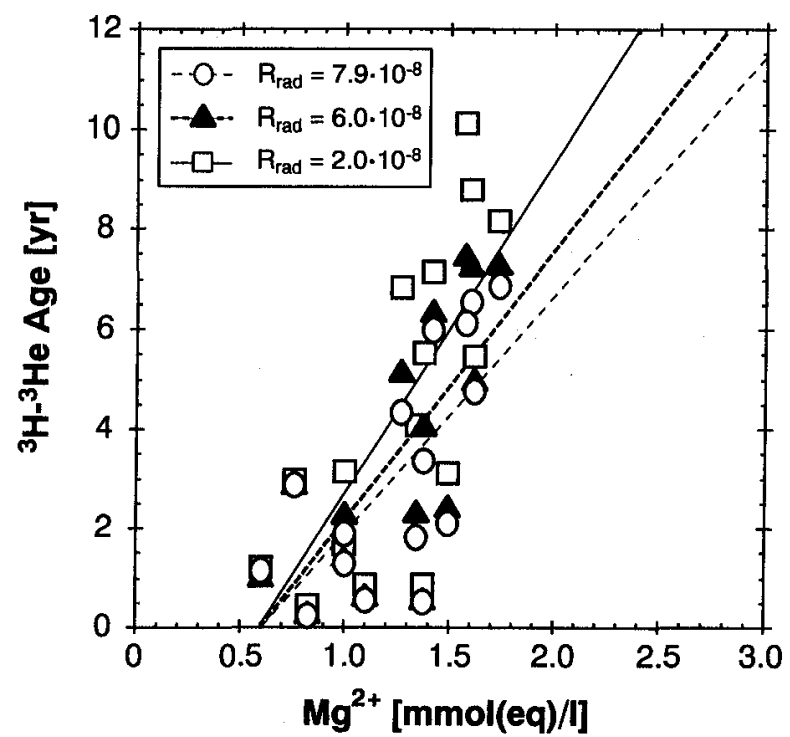

Figure 4. Determination of different $\mathrm{Mg}^{2+}$ accumulation rates for the limiting values of $\mathbf{R}_{\text {rad }}$ based on all ground water samples with robust ${ }^{3} \mathrm{H}-{ }^{3} \mathrm{He}$ ages that are insensitive to the choice of $R_{\text {rad }}$. Samples for which the calculated residence time is strongly linked to the chosen value of $R_{\text {rad }}$ (VBup; VB3, 9 m July 1998) are excluded.

${ }^{4} \mathrm{He}$ (VB3 [9 m, July 1999] and VBup), in which the calculated ages react sensitively to the choice of $R_{\mathrm{rad}}$. The relationship between ${ }^{4} \mathrm{He}_{\mathrm{rad}}$ and residence time is nonlinear, independently of the chosen value for $\mathbf{R}_{\text {rad }}$ (Figure 3 ). Nevertheless, the water ages must increase with increasing amounts of ${ }^{4} \mathrm{He}_{\mathrm{rad}}$ since the sources of ${ }^{4} \mathrm{He}_{\mathrm{rad}}$ are the same in all parts of the system. $R_{\mathrm{rad}}=7.9 \cdot 10^{-8}$ is therefore the upper limit for a realistic value for $R_{\text {rad }}$ because only $R_{\text {rad }} \leqslant 7.9 \cdot 10^{-8}$ yields for VBup a ${ }^{3} \mathrm{H}^{3} \mathrm{He}$ age that is the oldest of all samples. For larger values of $\mathrm{R}_{\mathrm{rad}}$, the ${ }^{3} \mathrm{H}-{ }^{3} \mathrm{He}$ age decreases with increasing ${ }^{4} \mathrm{He} \mathrm{rad}_{\mathrm{rad}}$ concentrations, i.e., the calculated age for VBup becomes smaller than that for VB3 (9 m, July 1998), although VB3 contains less ${ }^{4} \mathrm{He}_{\mathrm{rad}}$ than VBup (Figure 3).

The most realistic value for $R_{\mathrm{rad}}$ has to lie between the upper limit of $7.9 \cdot 10^{-8}$ and the radiogenic value of $2 \cdot 10^{-8}$, but it cannot be constrained further based on the noble gas data alone.

Here, the hydrochemistry data can assist in determining $\mathrm{R}_{\mathrm{rad}}$. In aquifers dominated by carbonate dissolution, the $\mathrm{Mg}^{2+}$ concentrations may trace the increasing maturity of ground water and hence the residence time (Herczeg and Edmunds 2000). The release of $\mathrm{Mg}^{2+}$ by calcite dissolution results in an increase in $\mathrm{Mg}^{2+}$ concentrations with increasing residence time until a geochemical equilibrium is reached. Since calcite dissolution is an important process in the aquifer studied, we used $\mathrm{Mg}^{2+}$ as an independent variable for a qualitative age indication that measures the ongoing dolomite dissolution. A temporal accumulation rate for $\mathrm{Mg}^{2+}$ could be defined for the study area (Figure 4). The samples with small amounts of ${ }^{4} \mathrm{He}_{\mathrm{rad}}$ and robust ${ }^{3} \mathrm{H}-{ }^{3} \mathrm{He}$ ages that are insensitive to the choice of $\mathrm{R}_{\mathrm{rad}}$ were used to define the $\mathrm{Mg}^{2+}$ accumulation rate, whereas the ${ }^{4} \mathrm{He}_{\text {rad }}$-rich samples VBup and VB3 (9 m, July 1998) were excluded. The ${ }^{3} \mathrm{H}-{ }^{3} \mathrm{He}$ ages were determined for $\mathrm{R}_{\mathrm{rad}}=$ $7.9 \cdot 10^{-8}$ and $\mathrm{R}_{\mathrm{rad}}=2.0 \cdot 10^{-8}$, resulting in two distinct accumulation rates. Table 4 compares the ${ }^{3} \mathrm{H}-{ }^{3} \mathrm{He}$ ages depending on the choice of $\mathrm{R}_{\mathrm{rad}}$ for VBup and VB3 (9 m, July 1998) with their corresponding $\mathrm{Mg}^{2+}$ accumulation ages. The agreement between the two independently calculated ages of the two samples depends strongly 


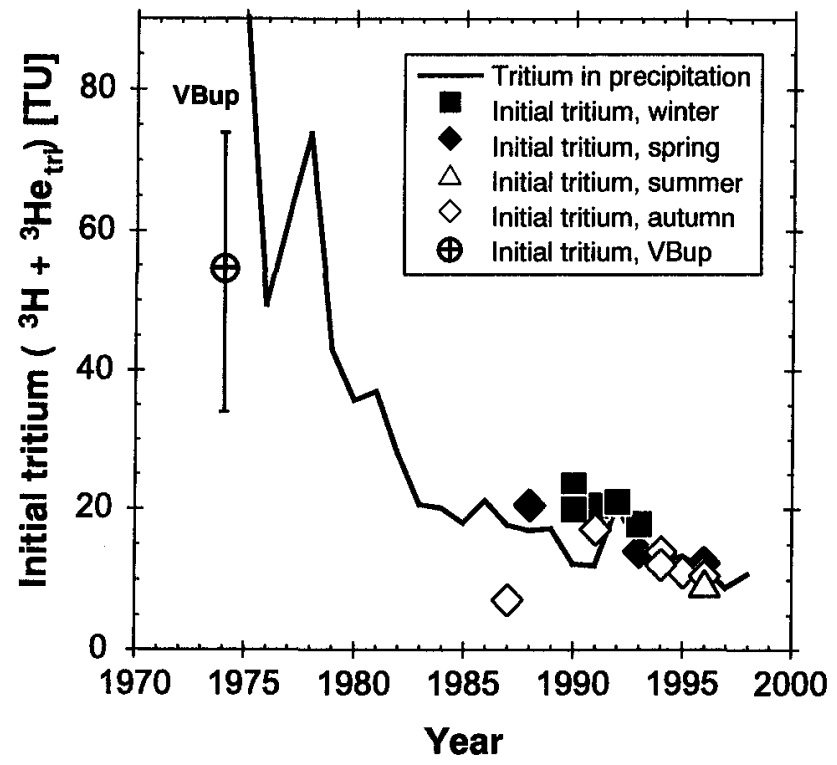

Figure 5. Tritium record in the precipitation at Locarno, Ticino, Switzerland, and the initial tritium concentrations $\left({ }^{3} \mathrm{H}_{\text {meusured }}+\right.$ ${ }^{3} \mathrm{He}_{\text {tritionic }}$ [TU]) of the ground water samples. The samples are plotted on the time axis according to their ${ }^{3} \mathrm{H}-{ }^{3} \mathrm{He}$ ages. The initial ${ }^{3} \mathrm{H}$ concentrations correlate well with the ${ }^{3} \mathrm{H}$ record in the local precipitation. The correspondence adds further evidence that the value of $R_{\text {rad }}$ in this study was chosen correctly.

on the value assigned to $R_{\text {rad }}$. In this study, we therefore used an intermediate value of $6.0 \cdot 10^{-8}$ for $R_{\text {rad }}$, which minimizes the RMS deviation between the two differently calculated ages. To account for systematic uncertainties in defining $\mathrm{R}_{\mathrm{rad}}$, we assigned a relatively large error of $\pm 2.0 \cdot 10^{-8}$ to $R_{\mathrm{rad}}$.

To verify the apparent ground water ages that were calculated with the adopted value of $R_{\text {rad }}$, the initial tritium content of the samples can be compared with the tritium record of regional precipitation (Stute et al. 1997; Aeschbach et al. 1998). The initial tritium content is defined by the sum of the measured tritium concentration and the ${ }^{3} \mathrm{He}$ produced by tritium decay $\left({ }^{3} \mathrm{He}_{\text {tri }}\right.$ ) during ground water flow. The calculated initial tritium is compared to the tritium record in precipitation from Locarno, which is located about $40 \mathrm{~km}$ south of the Valle di Blenio (Figure 5). The Locarno record lists measured tritium data until 1998. Generally, the calculated initial tritium values agree well with the atmospheric tritium record; even the oldest sample VBup matches reasonably if we consider its error in age of seven years. As shown, the abundance of tritiogenic ${ }^{3} \mathrm{He}$ in VBup depends strongly on the value of $\mathrm{R}_{\text {rad }}$ used in the ${ }^{3} \mathrm{H}-{ }^{3} \mathrm{He}$ age calculations (Figure 3 ). Therefore, the agreement between the initial tritium content of VBup and the corresponding tritium concentration in precipitation supports the choice of $R_{\mathrm{rad}}=$ $6.0 \cdot 10^{-8} \pm 2.0 \cdot 10^{-8}$ to calculate the ${ }^{3} \mathrm{H}-{ }^{3} \mathrm{He}$ ages.

In summary, we have established local values of the radiogenic ${ }^{3} \mathrm{He} /{ }^{4} \mathrm{He}$ ratio $\mathrm{R}_{\mathrm{rad}}$ and the $\mathrm{He} / \mathrm{Ne}$ ratio of the excess air component $\mathrm{L}_{\mathrm{exc}}$ that are used in this study. Despite the importance of these two parameters for the calculation of the tritiogenic $3 \mathrm{He}$ component (Equation 2) and the corresponding ${ }^{3} \mathrm{H}-{ }^{3} \mathrm{He}$ ages (Plummer et al. 2000), they are often poorly determined. The analysis and comprehensive interpretation of all noble gases and the additional use of a geochemical maturity indicator can significantly improve the quality of the ${ }^{3} \mathrm{H}-{ }^{3} \mathrm{He}$ ground water age determination, particularly if larger excess air and radiogenic components are present.

\section{Results and Discussion}

\section{Ground Water Head Data}

The ground water levels in the floodplain show a definite seasonal variation. Throughout the winter season they are generally low, showing the influence of temporary storage of precipitation in the snow cover, which decreases active ground water recharge and hence the ground water levels in the floodplain. With the beginning of snowmelt in spring, the water levels rise. In summer, infiltration of fresh water into the aquifer leads to high ground water heads that fluctuate only slightly in response to precipitation events. As the fresh water supply is reduced in autumn, the ground water levels decrease, again attaining their minimal values in winter. The absolute annual changes of the ground water heads vary between $20 \mathrm{~cm}$ (VB3) and $7.30 \mathrm{~m}$ (VB2). The water level fluctuations are small in the wells that are close to the active River Brenno bed (VB3, VB4, VB6), whereas the more distant wells (VB2, VB1, VB5) are subject to much stronger changes. Generally, the ground water levels in all wells lie above the riverine water level of the Brenno throughout the entire year.

\section{Hydrochemistry and Water Components}

The hydrochemisty of the middle floodplain, Valle di Blenio, is dominated by the major ions calcium $\left(\mathrm{Ca}^{2+}\right)$, magnesium $\left(\mathrm{Mg}^{2+}\right)$, bicarbonate $\left(\mathrm{HCO}_{3}{ }^{-}\right)$and sulfate $\left(\mathrm{SO}_{4}{ }^{2-}\right)$. Figure 6 depicts the composition of the water samples in terms of these major ion components, which comprise $95 \%$ or more of the total dissolved solids. Two hydrochemical components can be distinguished: water from the River Brenno (Brenno water) and water from the floodplain (floodplain water). The Brenno water defines the samples from the Brenno itself and from the piezometers in its active riverbed (PQ). The floodplain water represents the six wells (VB1 to VB6), the floodplain piezometers (PU) and samples from the Uregn tributary. The Brenno water is characterized by high sulfate and low bicarbonate concentrations; in contrast, the floodplain water has high $\mathrm{HCO}_{3}{ }^{-}$and low $\mathrm{SO}_{4}{ }^{2-}$ concentrations. The differences in the cationic composition are less pronounced. The Brenno water contains a somewhat greater proportion of calcium and a smaller proportion of magnesium than the floodplain water, although calcium is the dominant cation in both water components (Tables 1 and 2). The Brenno water is classified as $\mathrm{Ca}-\mathrm{SO}_{4}$ water and the floodplain water as $\mathrm{Ca}-\mathrm{HCO}_{3}$ water.

This separation documents the influence of the geological setting on the hydrochemistry of the system. The floodplain with the River Uregn, together with the ground water system (wells and piezometers $\mathrm{PU}$ ) define one hydrochemical unit that is governed by the carbonates and metamorphic rocks of the hillslope. In contrast, the Brenno water that controls the hydrochemistry of the waters in the active river bed gains its characteristically high $\mathrm{SO}_{4}{ }^{2-}$ concentration by upstream dissolution of anhydrite in the upper part of the Val di Lucomagno and sulfate-rich inflows from the neighbouring anhydrite-rich Val Piora.

The chemistry of the Brenno as well as that of the floodplain water in the major tributary Uregn and in the piezometers PU remains largely constant throughout the year (Figure 6). The composition of the floodplain water in the wells, however, shows a seasonal variation. The well samples taken in winter are generally more mineralized than during the rest of the year, with the largest increase in $\mathrm{SO}_{4}{ }^{2-}$ concentrations (Table 1). Because in winter the fresh water supply to the aquifer is reduced, the proportion of older, 

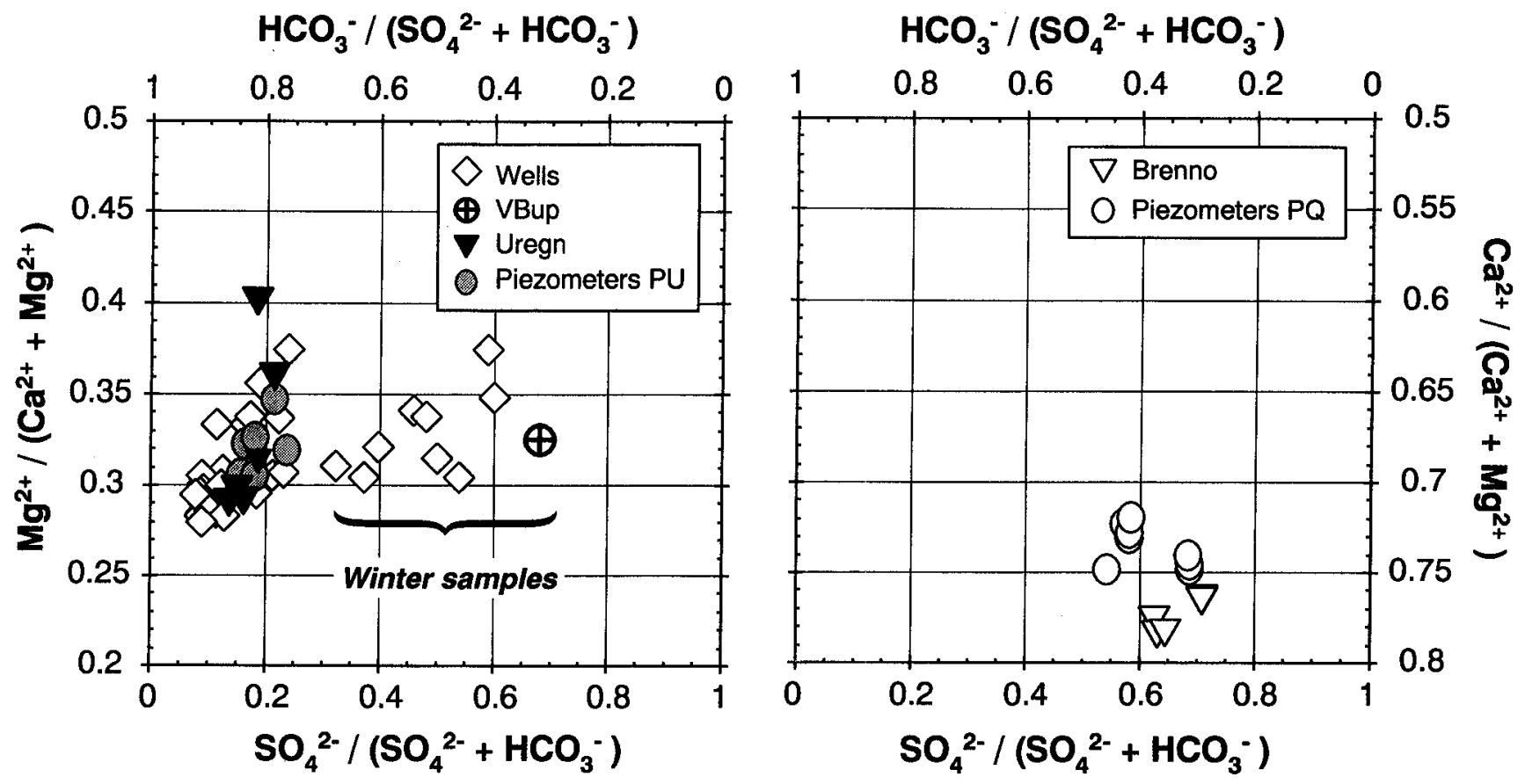

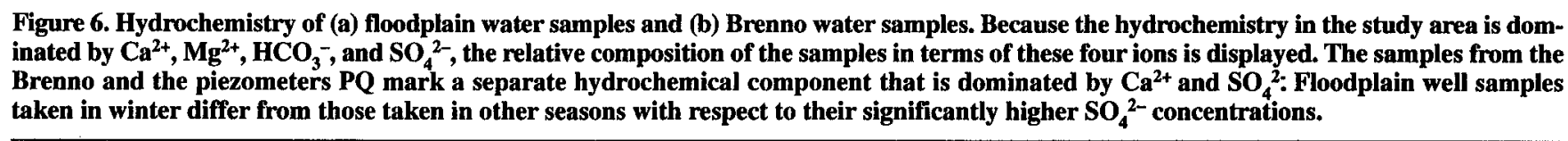

higher mineralized water in the wells increases. However, short warmer periods can lead to temporary dilution effects by snowmelt water. This explains the spread that is present in the hydrochemistry of the winter samples, ranging between the highly mineralized composition of the ground water sample from VBup and the rather fresh composition of the samples VB1, VB2, and VB3 taken in February 1999 (Table 1). In contrast, during the summer season all wells show the influence of recently infiltrated fresh water, which manifests itself in less mineralization and higher ground water levels.

Apart from the seasonal variation, a spatial variation can also be found in the floodplain ground water samples. Looking at VB3 in May and July, the ground water in the well is divided vertically into two zones: an upper layer with the low ion concentrations typical of the summer situation, and a deeper layer with higher ion concentrations and a hydrochemical composition similar to that of the highest mineralized ground water sample VBup. The $\mathrm{Ca}-\mathrm{HCO}_{3}$-floodplain water in the aquifer can therefore be subdivided into two chemical facies of the same general type (Figure 7a): near-surface water (summer component) that is less mineralized (Table 1) and more highly mineralized, evolved ground water (winter component), which is present also in summer in the deeper layer of VB3.

The results of Pastorelli et al. (1999), who analyzed different cold and warm springs in the Valle di Blenio, corroborate the conceptual interpretation in terms of two geochemical facies in the floodplain aquifer. The springs from the western hillslopes between Acquarossa and Grumo are all of $\mathrm{Ca}-\mathrm{HCO}$ to $\mathrm{Ca}-\mathrm{HCO}_{3}-\mathrm{SO}_{4} \mathrm{com}$ position, and their in situ temperatures correspond to the mean annual air temperature. Pastorelli et al. (1999) interpret the $\mathrm{Ca}-\mathrm{HCO}_{3}$ springs as the result of rock/water interaction of meteoric water with gneisses and dolomites. In their view, the $\mathrm{Ca}-\mathrm{HCO}_{3}-\mathrm{SO}_{4}$ springs represent a more evolved variety of this fresh $\mathrm{Ca}-\mathrm{HCO}_{3}$ water type. This interpretation is in accordance with our distinction of two geochemical facies in the floodplain with a fresh summer water type of $\mathrm{Ca}-\mathrm{HCO}_{3}$ composition and a more evolved winter water type that tends toward a $\mathrm{Ca}-\mathrm{HCO}_{3}-\mathrm{SO}_{4}$ composition.

Pastorelli et al. (1999) also analysed one spring from the Passo di Lucomagno, which shows clearly the $\mathrm{Ca}-\mathrm{SO}_{4}$ composition of water from the upper Lucomagno region that is described as Brenno water in our study.

\section{${ }^{3} \mathrm{H}-{ }^{3}$ He Dating and Noble Gas Data}

The ground water ages support the conceptual picture of two geochemically distinct ground water zones, as implied by the hydrochemical data. In winter, all water ages are relatively high (four to seven years). These high ages correspond to the geochemically more evolved winter ground water component.

The sample of the upwelling ground water at VBup is ${ }^{3} \mathrm{H}$-active and highly enriched in radiogenic ${ }^{4} \mathrm{He}\left({ }^{4} \mathrm{He}_{\mathrm{rad}}=98 \%\right.$ of $\left.{ }^{4} \mathrm{He} \mathrm{e}_{\text {tot }}\right)$. The simultaneous occurrence of ${ }^{3} \mathrm{H}$ and ${ }^{4} \mathrm{He}_{\mathrm{rad}}$ may be interpreted as a mixture of old, tritium-free water and ground water of the regular winter type. Although an exact separation of these components is not possible based on the data available, there are two strong arguments for believing that only a minor proportion of the VBup water can be tritium-free. First, the calculated initial tritium content of the VBup sample agrees well with the tritium content of the precipitation at the time of infiltration (Figure 5). Second, tritium-free ground water found in the Valle di Blenio is deep, geothermal 

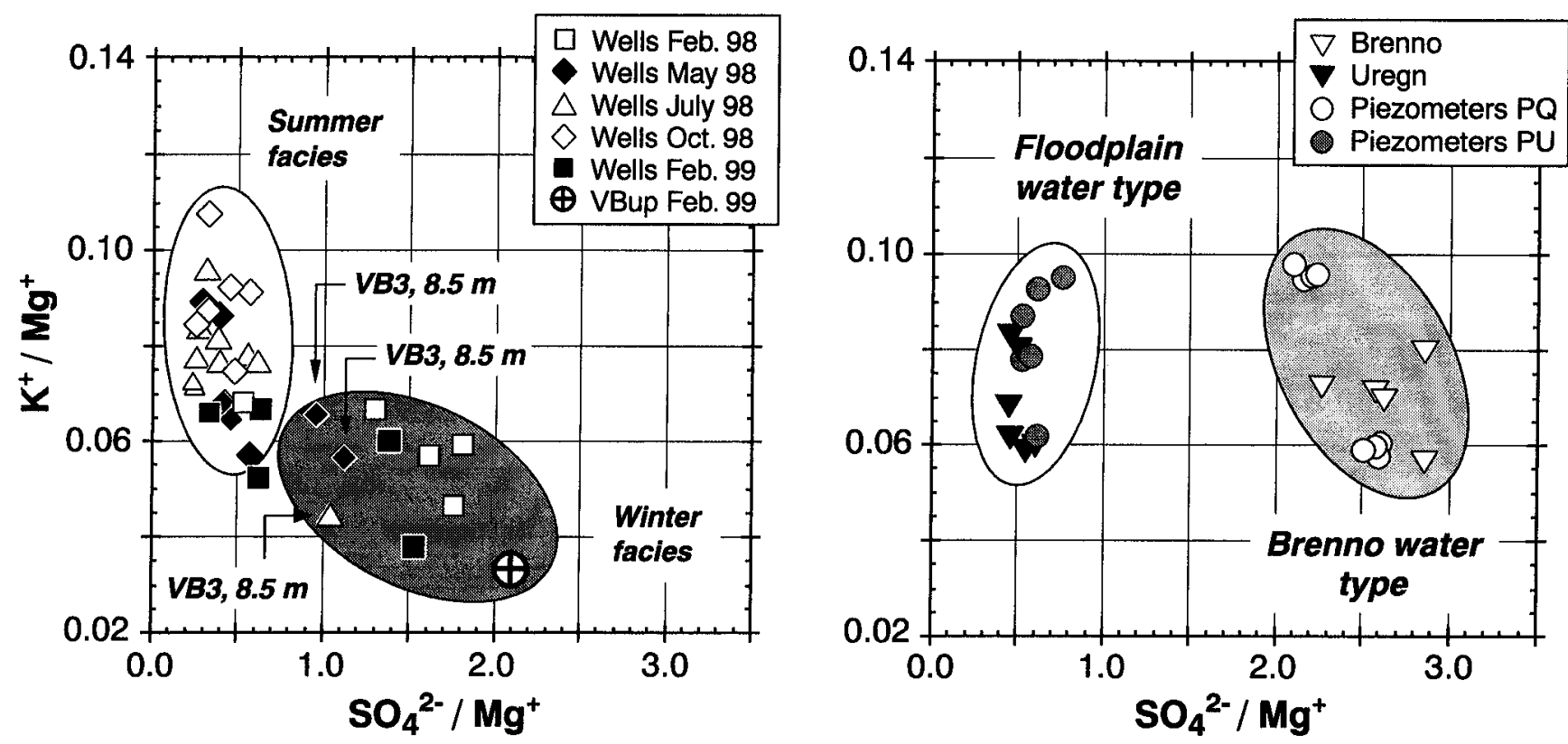

Figure 7. Hydrochemistry of (a) ground water samples and (b) surface and near-surface water samples expressed as $\mathrm{K}^{+} / \mathrm{Mg}^{2+}$ versus $\mathrm{SO}_{4}{ }^{2-} /$ $\mathrm{Mg}^{2+}$ molar ratios. Within the surface water samples the separation in floodplain water (Uregn and piezometers [PU]) and Brenno water (Brenno and piezometers [PQ]) is obvious. Within the ground water samples, two hydrochemical facies exist. The winter samples represent a more evolved ground water type whereas the summer samples contain recently infiltrated fresh water.

water with total dissolved solids (TDS) exceeding $2400 \mathrm{mg} / \mathrm{L}$ (Mazor and Vuataz 1990). The temperature of VBup and its lower mineral content (TDS $=1230 \mathrm{mg} / \mathrm{L}$ ) therefore preclude a major contribution of such tritium-free geothermal water to the upwelling ground water at VBup.

In spring, the apparent ages in the wells decrease to one to four years, reflecting increasing dilution with recently infiltrated snowmelt water. An exception is VB3: the vertical layering observed in the hydrochemical composition is also reflected in the age distribution. In spring, the age of the upper layer is 5.7 years, as opposed to 8.2 years in the case of the bottom layer.

In summer, the tritium concentration of only one sample (VB6) was measured. However, since the ${ }^{3} \mathrm{H}$ concentrations measured in the wells do not vary significantly during the investigation, one can approximate the summer tritium concentration by the average ${ }^{3} \mathrm{H}$ concentration of all samples taken in May, July, and October 1998. Variation of this average summer ${ }^{3} \mathrm{H}$ concentration within the $2 \sigma$ range does not change the calculated age distribution pattern for the summer situation at all. Although a simplification, the assumption of an average summer ${ }^{3} \mathrm{H}$ concentration is therefore nevertheless reasonable.

Using the approximated ${ }^{3} \mathrm{H}$ concentration of $10.4 \pm 2.4 \mathrm{TU}$ for the summer situation, the estimated ages in wells VB1 to VB5 are all less than 1.5 years. Well VB3 is again an exception. The bottom water layer in summer 1998 is much older (18 years), which agrees well with the high mineralization and emphasizes the close relationsship of this bottom water in VB3 to the old ground water upwelling at VBup. In contrast, the upper water layer of VB3 in summer has an average water age of only $2.8 \pm 1.1$ years.

During autumn, all water ages evolve generally toward the winter situation characterized by higher ages. Only VB2 still shows a low water age. This well, which generally exhibits very low ages, is apparently most strongly influenced by near-surface water from the hillslope.

\section{Hydrological System}

Based on the information obtained from geochemical and noble gas data, we suggest the following conceptual model describing the hydrological system of the middle floodplain of the Valle di Blenio and its temporal dynamics (Figure 8). The aquifer system of the floodplain consists of two layers: a near-surface zone fed by surface water (precipitation, snowmelt water, water from tributaries) and a deeper zone containing geochemically evolved ground water. Although this separation into two vertical aquifer zones is based only on the prevailing hydrochemical water types and the ${ }^{3} \mathrm{H}-{ }^{3} \mathrm{He}$ water ages, it is consistent with the schematic circulation model of the Acquarossa spring system proposed by Pastorelli et al. (1999). They described the shallow ground water system in the western part of the Valle di Blenio as a near-surface cold aquifer developed in the Mesozoic sediment cover of the western hillslope of the Blenio valley. The deeper zone of the investigated floodplain aquifer is most likely located in this Mesozoic cover, which results in higher ground water residence times and a higher degree of mineralization compared to the upper ground water zone. The near-surface zone is established in the carbonate-rich detritals and fluvial deposits of the Brenno tributaries and the Brenno itself that overlie the Mesozoic sediment cover in the lower hillslope area. A sharp separation of the two geochemical facies and a definite assignment of these geochemical facies to the two geological facies is not possible and also not intended by this conceptual approach. Although the two aquifer zones are not separated by any aquiclude, the geochemical separation within the aquifer is evident and expresses its presence in the ver- 


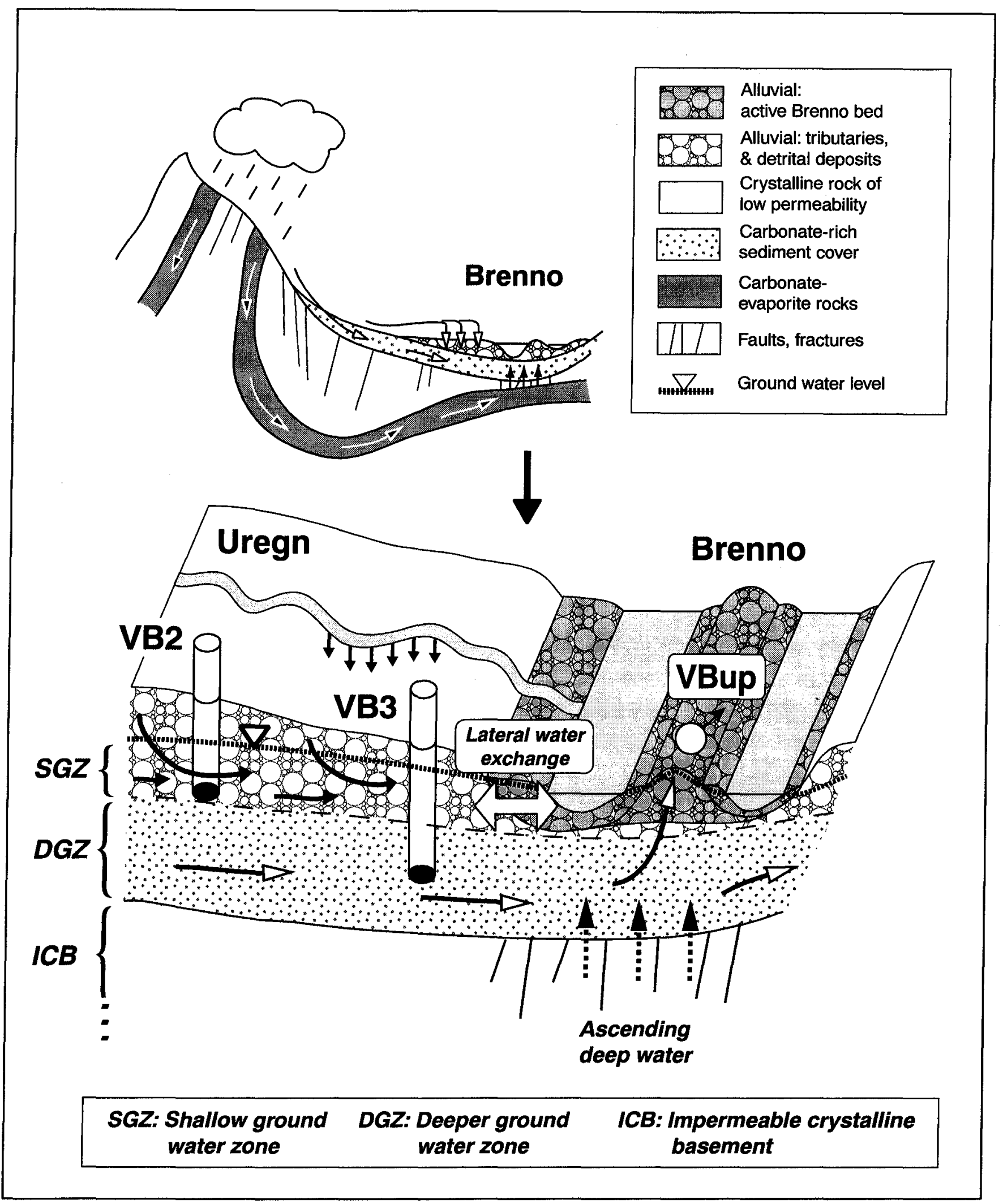

Figure 8 Conceptualized hydrological system of the middle floodplain of Valle di Blenio. The ground water system is divided into a nearsurface level with younger, only slightly mineralized water (recently infiltrated rainwater, snowmelt water; inflow from the upper parts of the hillslope) and a deeper, more highly mineralized zone with older, geochemically evolved ground water. This distinction is associated with a hydrogeological separation within the aquifer. Note that the surface of the tributary alluvial layer was left white for reasons of clarity. The upwelling ground water at VBup is most likely influenced by ascending deep, mildy thermal water. Exfiltration of near-surface ground water toward the Brenno is possible, whereas major vertical exchange processes between the deeper ground water zone and the Brenno seem not be present. 
tical stratification of the two geochemcial facies. Generally, the deeper ground water samples from wells near the Brenno (e.g., in the bottom layer of VB3) show the influence of the geochemically evolved ground water facies, while in the more distant boreholes (e.g., VB2) this evolved ground water component is not obviously present. Looking at the hydrochemical data of the wells near the Brenno (Table 1), a seasonal variation in the depth of the transition between the two ground water facies in accordance to the changes in ground water levels with a higher position in summer and a lower localization in winter is most likely.

Pastorelli et al. (1999) also describe a hydrothermal ground water system in the Valle di Blenio in which deep, relatively permeable, carbonate-rich layers are separated by basement nappes of crystalline rocks, both of them transformed by back-folding processes. Since the crystalline rocks are most likely fractured, the deeper zone of the floodplain aquifer may possibly be influenced by upflowing hydrothermal water from deeper strata. However, the water temperature and the degree of mineralization of the samples analyzed are generally much too low to be interpreted as a mixture of cold, near-surface ground water, and deep thermal water. Only VBup may show a small portion of such thermal waters. According to Mazor and Vuataz (1990) and Pastorelli et al. (1999), deep and warm ground water ascends along faults and fractures in the gneissic basement and forms the geothermal spring complex in close vicinity to the Brenno north of Aquarossa. VBup is located very close to this stress zone and can therefore realistically be described in terms of a mixture of a relatively small proportion of an old, mildly geothermal component with younger, fresher ground water.

Of interest is the water exchange between the ground water system in the floodplain and the River Brenno. The Brenno acts as the discharge level for the near-surface aquifer, allowing active water exchange between the river and the shallow ground water, mainly by ground water exfiltration. In contrast to the shallow ground water, the deeper and older ground water zone of the aquifer seems to be rather isolated from the river in that no dilution effect can be evidenced in the deeper ground water zone. This separation is strongly supported by the geochemical composition of VBup and the deeper water in VB3, which implies that river water infiltration does not exist in the deeper ground water layer. Considering both aspects, water exchange occurs mainly horizontally between the near-surface ground water and the river water, whereas the geochemical zoning excludes major vertical water exchange processes.

\section{Conclusions}

The present study attempts to characterize the hydrology of an alpine floodplain, Valle di Blenio, using hydrochemical data and ${ }^{3} \mathrm{H}-{ }^{3} \mathrm{He}$ water ages. The use of $\mathrm{Mg}^{2+}$ as a tracer of ground water maturity and the comprehensive interpretation of all five noble gases in terms of excess air fractionation enabled appropriate values for the radiogenic ${ }^{3} \mathrm{He} /{ }^{4} \mathrm{He}$ ratio and the $\mathrm{He} / \mathrm{Ne}$ ratio of the excess air component in the studied area to be adopted. The correct determination of these two parameters significantly improves the accuracy of the derived ${ }^{3} \mathrm{H}-{ }^{3} \mathrm{He}$ water ages.

The interpretation of the hydrochemical data and the calculated water ages indicate a geochemical separation between the River Brenno and its active riverbed on the one hand, and the floodplain water in the aquifer and the hillslope on the other. The floodplain water is $\mathrm{Ca}-\mathrm{HCO}_{3}{ }^{-}$-dominated, with two geochemical facies. The first facies represents a fresh, young summer component of recently infiltrated near-surface water that is present in the floodplain wells, in the Uregn tributary, and in the piezometers PU. The second facies is characterized by older, more evolved, deeper ground water that is present in the deeper zone of the aquifer and in the upwelling ground water at VBup. During winter, lower water levels in the floodplain aquifer are associated with a hydrochemical composition of the well samples that tends toward that of the evolved geochemical facies. Water exchange between ground water and Brenno water occurs mainly as exfiltration of shallow ground water. The deeper ground water zone is geochemically separated from the upper ground water and shows no evidence of river water infiltration.

\section{Acknowledgments}

We would like to thank E. Hoehn for his help in field sampling and discussions. A. Ammann performed the chemical analyses. U. Schotterer and H. Bürki provided the tritium record for the station Locarno from 1988 through 1998. This study was performed with substantial support from the Canton of Ticino as part of the multidisciplinary resarch program "Ökostrom" of the Swiss Federal Institute of Environmental Science and Technology (EAWAG). The manuscript was improved by reviews by F. E. Harvey and two anonymous reviewers.

\section{References}

Aeschbach-Hertig, W., P. Schlosser, M. Stute, H.J. Simpson, A. Ludin, and J.F. Clark. 1998. ${ }^{3} \mathrm{H} /{ }^{\beta} \mathrm{He}$ study of ground water flow in a fractured bedrock aquifer. Ground Water 36, no. 4: 661-670.

Aeschbach-Hertig, W., F. Peeters, U. Beyerle, and R. Kipfer. 1999. Interpretation of dissolved atmospheric noble gases in natural waters. Water Resour. Res. 35, no. 9: 2779-2792.

Aeschbach-Hertig, W., F. Peeters, U. Beyerle, and R. Kipfer. 2000. Palaeotemperature reconstruction from noble gases in ground water taking into account equilibration with entrapped air. Nature 405, no. 6790:1040-1044.

Alden, A.S., and C.L. Munster. 1997. Assessment of river-floodplain aquifer interactions. Environ. Eng. Geoscience 3, no. 4: 537-548.

Ammann, P. 1973. Geologia e petrografia della regione del Pizzo Molare. Ph.D. diss. ETH Nr. 5282, ETH Zurich.

Andrews, J.N. 1992. Mechanisms for noble gas dissolution by groundwaters. In Proceedings of Isotopes of Noble Gases as Tracers in Environmental Studies, 87-110. Vienna: International Atomic Energy Agency.

Beyerle, U., W. Aeschbach-Hertig, M. Hofer, D.M. Imboden, H. Baur, and R. Kipfer. 1999. Infiltration of river water to a shallow aquifer investigated with $3 \mathrm{H} / 3 \mathrm{He}$, noble gases and CFCs. J. Hydrol. 220, nos. 3-4: 169-185.

Beyerle, U., W. Aeschbach-Hertig, D.M. Imboden, H. Baur, T. Graf, and R. Kipfer. 2000. A mass spectrometric system for the analysis of noble gases and tritium from water samples. Env. Sci. Technol. 34, no. 10: 2042-2050.

Bradley, C. 1996. Transient modelling of water-table variation in a floodplain wetland, Narborough Bog, Leicestershire. J. Hydrol. 185, nos. 1-4: 87-114.

Clarke, W.B., W.J. Jenkins, and Z. Top. 1976. Determination of tritium by mass spectrometric measurement of ${ }^{3} \mathrm{He}$. Int. J. Appl. Radiat. Isotopes 27, no. 9: 515-522.

Dunkle Shapiro, S., D. LeBlanc, P. Schlosser, and A. Ludin. 1999. Characterizing a sewage plume using the ${ }^{3} \mathrm{H}-{ }^{3} \mathrm{He}$ dating technique. Ground Water 37, no. 6: 861-878.

Herczeg, A.L., and W.M. Edmunds. 2000. Inorganic ions as tracers. In Environmental Tracers in Subsurface Hydrology, ed. P.C. Cook and A. L. Herczeg, 31-77. Boston: Kluwer Academic Publishers.

Heaton, T.H.E., and J.C. Vogel. 1981. "Excess air" in groundwater. $J$. Hydrol. 50, nos. 1-4: 201-216.

Heaton, T.H.E. 1984. Rates and sources of ${ }^{4} \mathrm{He}$ accumulation in groundwater. Hydrol. Sci.J. 29, no. 1: 29-47. 
Hemond, H.F. 1980. Biogeochemistry of Thoreau's Bog, Concord, Massachusetts. Ecological Monographs 50, no. 4: 507-526.

Kipfer, R. 1991. Primordiale Edelgase als Tracer für Fluide aus dem Erdmantel. Ph.D. diss. ETH Nr. 9463, ETH Zurich.

Lucas, L.L., and M.P. Unterweger. 2000. Comprehensive review and critical evaluation of the half-life of tritium. J. Res. Natl. Inst. Stand. Technol. 105, no. 4: 541-549.

Mamyrin, B.A., and I.N. Tolstikhin. 1984. Helium isotopes in nature. In Developments in Geochemistry, ed. W. S. Fyfe. New York: Elsevier.

Mazor, E., and F.D. Vuataz. 1990. Hydrology of a spring complex, studied by geochemical time-series data, Acquarossa, Switzerland. Appl. Geochem. 5, nos. 5-6: 563-569.

Mengis, M., S.L. Schiff, M. Harris, M.C. English, R. Avarena, R.J. Elgood, and A. MacLean. 1999. Multiple geochemical and isotopic approaches for assessing ground water $\mathrm{NO}_{3}^{-}$elimination in a riparian zone. Ground Water 37, no. 3: 448-457.

Pastorelli, S., L. Marini, and J.C. Hunziker. 1999. Water chemistry and isotope composition of the Acquarossa thermal system, Ticino, Switzerland. Geothermics 28, no. 1: 75-93.

Plummer, L.N., M.G. Rupert, E. Busenberg, and P. Schlosser. 2000. Age of irrigation water in ground water from the eastern Snake River Plain Aquifer, south-central Idaho. Ground Water 38, no. 2: 264-283.

Preiswerk, H., L. Bossard, O. Grütter, P. Niggeli, E. Kündig, and E. Ambühl. 1934. Geologische Karte der Tessineralpen zwischen Maggia- und Bleniotal. Geologische Karte der Schweiz, Spezialkarte Nr. 116.

Rapp, M.C., C. Fulda, W. Schäfer, and W. Kinzelbach. 1998. The dual pumping technique (DPT) for level-determined sampling in a fully screened groundwater well. J. Hydrol. 207, nos. 3-4: 220-235.
Schlosser, P., M. Stute, C. Sonntag, and K.O. Münnich. 1989. Tritiogenic ${ }^{3} \mathrm{He}$ in shallow groundwater. Earth Planet. Sci. Lett. 94, nos. 3-4: 245-256.

Stute, M., C. Sonntag, J. Déak, and P. Schlosser. 1992. Helium in deep circulating groundwater in the Great Hungarian Plain: Flow dynamics and crustal and mantle helium fluxes. Geochim. Cosmochim. Acta 56, no. 5: 2051-2067.

Stute, M., and P. Schlosser. 1993. Principles and applications of the noble gas paleothermometer. In Climate Change in Continental Isotopic Records, ed. P.K. Swart, K.C. Lohmann, J. McKenzie, and S. Savin, Geophysical Monograph 78, 89-100. Washington, D.C.: American Geophysical Union.

Stute, M., M. Forster, H. Frischkorn, A. Serejo, J.F. Clark, P. Schlosser, W. S. Broecker, and G. Bonani. 1995. Cooling of tropical Brazil $\left(5^{\circ} \mathrm{C}\right)$ during the Last Glacial Maximum.Science 269, no. 5222: 379-383.

Stute, M., J. Deák, K. Révész, J.K. Böhlke, É. Beseö, R. Weppernig, and P. Schlosser. 1997. Tritium $/{ }^{\beta} \mathrm{He}$ dating of river infiltration: An example from the Danube in the Szigetkös area, Hungary. Ground Water 35, no. 5: 905-911.

Tolstikhin, I.N., and I.L. Kamenskiy. 1969. Determination of ground-water ages by the T- ${ }^{3} \mathrm{He}$ Method. Geochemistry International $6,810-811$.

Tockner, K., D. Pennetzdorfer, N. Reiner, F. Schiemer, and J.V. Ward. 1999. Hydrological connectivity and the exchange of organic matter and nutrients in a dynamic river-floodplain system (Danube, Austria). Freshwater Biol. 41, no. 3: 521-535.

Ward, J.V., K. Tockner, and F. Schiemer. 1999. Biodiversity of floodplain river ecosystems: Ecotones and connectivity. Reg. Riv.: Res. \& Manag. 15, no. 1-3: 125-139.

Wilson, G.B., and G.W. McNeill. 1997. Noble gas recharge temperatures and the excess air component. Appl. Geochem. 12, no. 6: 747-762. 